\title{
Blood rheology as a mirror of endocrine and metabolic homeostasis in health
}

\section{and disease ${ }^{1}$}

Jean-Frédéric Brun ${ }^{\mathrm{a}, *}$, Emmanuelle Varlet-Marie ${ }^{\mathrm{b}, \mathrm{c}}$, Marlène Richou ${ }^{\mathrm{a}}$, Jacques Mercier ${ }^{\mathrm{a}}$ and Eric Raynaud de Mauverger ${ }^{\mathrm{a}}$

${ }^{\mathrm{a}}$ U1046 INSERM, UMR 9214 CNRS «Physiopathologie and Médecine Expérimentale du Coeur et des Muscles-PHYMEDEXP », Unité d'Explorations Métaboliques (CERAMM), Université de Montpellier, Département de Physiologie Clinique, Hôpital Lapeyronie CHRU Montpellier, France ${ }^{\mathrm{b}}$ Institut des Biomolécules Max Mousseron (IBMM) UMR CNRS 5247, Université de Montpellier, Ecole Nationale Supérieure de Chimie de Montpellier, France ${ }^{ }$Laboratoire de Biophysique and Bio-Analyses, Faculté de Pharmacie, Université de Montpellier, France

Abstract. Rheological properties of plasma and blood cells are markedly influenced by the surrounding milieu: physicochemical factors, metabolism and hormones. Acid/base status, osmolality, lipid status, plasma protein pattern, oxidative stress induced by increased free radicals production, endothelium-derived factors such as nitric oxide (NO), achidonic acid derivatives modulate both red blood cell (RBC) and white cell mechanics. Therefore, regulatory axes involving liver, endothelium, kidney, pancreas, adrenal gland, endocrine heart, adipose tissue, pituitary gland, and surely other tissues play important roles in the regulation of blood fluidity. A comprehensive picture of all this complex network of regulatory loops is still unavailable but current progress of knowledge suggest that some attempts can currently be made.

Keywords: Erythrocyte, viscosity, deformability, aggregation, hormones, metabolism

\section{Abbreviations}

ATP adenosine triphosphate

cAMP cyclic adenosine monophosphate

EPO erythropoietin

NMDA N-methyl D-aspartate

NO nitric oxide

NOS nitrous oxide system

OSAS obstructive sleep apnea syndrome

PAI-1 plasminogen activator inhibitor-1

RBC red blood cell

TBARS thiobarbituric acid reactive substances

$\mathrm{TCPO}_{2}$ : transcutaneous oxide partial pressure determination

\footnotetext{
${ }^{1}$ The manuscript is dedicated to Prof. F. Jung on the occasion of his 70th birthday.

*Corresponding author: Brun Jean-Frédéric, MD, PhD, U1046 INSERM, UMR 9214 CNRS « Physiopathologie and Médecine Expérimentale du Coeur et des Muscles-PHYMEDEXP », Unité d'Explorations Métaboliques (CERAMM), Université de Montpellier, Département de Physiologie Clinique, Hôpital Lapeyronie CHRU Montpellier, France. Tel.: +33467338284; Fax: +33467338986; Telex: CHR MONTP 480766 F; E-mail: j-brun@ chu-montpellier.fr.
} 


\section{Introduction}

The rheological properties of blood are classically assumed to be an important determinant of blood flow and tissue oxygen delivery, according to the classical Poiseuille law [144, 148]. Over the last decades, this issue has been the matter of extensive studies showing that the picture is more complex, due to the non-linearity of the effects of blood viscosity factors on blood circulation and oxygen supply. First of all, due to the ability of the normal vessel wall to release vasoactive substances, it has been shown that moderate increases in blood viscosity as usually found in health and diseases result in a vasodilation-driven increase of blood flow [121]. Further increases in viscosity, obviously, result in a rise in resistance to flow and thus an impairment of tissue perfusion and oxygenation, as evidenced in so-called «hyperviscosity syndromes» [135]. In addition, in some situations where vasoactivity is impaired or immature, viscosity has also a deleterious effect on circulation, explaining why viscosity factors are involved in the risk of cardiovascular atherothrombotic events $[68,99,117$, $118,216]$.

On the other hand, the effect of blood viscosity factors on the structure of circulating blood is far to be linear and is rather a transition between to opposite states: a situation of high-pressure and high flow where blood is very fluid and behaves almost like a newtonian fluid [128], and a situation of low-pressure and low flow where blood aggregates develop resulting in a situation of very low fluidity $[26,30,171]$. H. Schmid-Schönbein has proposed to describe this heterophase transition effect with the 'percolation' mathematical model [172].

All these developments of modern hemorheology have markedly modified the paradigms [8]. Clearly a crude measurement of blood viscosity has little relevance and it is mandatory to separately take into account plasma viscosity, hematocrit, red cell deformability and red cell aggregation. All these parameters are in turn under the influence of many factors that have been extensively studied over the last 30 years.

In 2002, we proposed a review of the various influences of metabolic and hormonal parameters on the determinants of blood viscosity [24]. More than 15 years later it is interesting to tempt a new overview of this vast area of knowledge. We remind to the preceding review paper for the literature before 2001 and mostly emphasize the most recent findings examined under the light of the evolution of our knowledge of interactions between viscosity factors and blood supply to tissues. A more complete set of references can be provided to the reader by sending an email to the corresponding author of this review.

\section{Regulation of plasma viscosity}

Plasma is generally described as a newtonian fluid [95]. The normal value of its viscosity is $1.10-1.30 \mathrm{mPa} s$ at $37^{\circ} \mathrm{C}$. It has been assumed for a long time that it modulates the perfusion of microvessels because the absolute capillary hematocrit is about $10-20 \%$, so that blood viscosity in capillaries approaches plasma viscosity [5]. More recent studies by the team of H. Lipowski [114] are in agreement with this concept, as recently reviewed by F. Jung and M. Rampling [91]. A normal value of plasma viscosity is required, as demonstrated by an experiment in hamster window chamber model associating extreme hemodilution and high-viscosity plasma resulting in a very low hematocrit (11\%), a final blood viscosity at $2.8 \mathrm{cP}$ and a plasma viscosity at $2.2 \mathrm{cP}$. This experiment significantly elevated mean arterial pressure and cardiac output but did not increase vascular resistance [43]. This finding shows that there is a clear circulatory benefit to maintain blood rheological properties during hemodilution by increasing plasma viscosity: this sustains capillary pressure, 
increases microvascular flow, and increases the production of endothelium-mediated factors. Shear stress exerted by a more viscous plasma moving near the endothelial surface influences vessel diameter and modulates the release of autacoids (prostacyclin and nitric oxide). In a previous study using the same model and protocol, Tsai et al. [199] showed that increased wall shear stress is associated with an increase in the measured concentration of perivascular nitric oxide, with concomitant vasodilator effects. Therefore, the combination of vasodilation and increased flow due to higher plasma viscosity leads to an increased capillary pressure which in turn increases the recruitment of the capillary bed and tissue perfusion. However, this beneficial effect is likely to become inefficient if endothelial function is impaired, compromising the vasodilatory response. In that case, clearly, raised plasma viscosity should be expected to only increase resistance, as classically described in rigid tubes.

Accordingly, plasma viscosity has been demonstrated in prospective studies to be a predictor of vascular events $[100,160]$. It is likely that its newtonian behavior explains that it makes Poiseuille's law become true in atheromatous, poorly vasoactive vessels. In agreement with these assumptions, some years ago we observed that type 2 diabetic patients whose plasma viscosity is higher than $1.45 \mathrm{mPa}$.s exhibit a markedly higher blood pressure which did not appear to be explained by confounding variables, and we suggested that it was due to high plasma viscosity [34].

As recently reviewed by Késmárky [95], plasma viscosity is dependent on two components of this fluid: water and proteins.

Water content may be modified in physiological situations, resulting in concentration or dilution. A first situation where this can be evidenced is pregnancy. During normal pregnancies plasma viscosity decreased in the first trimester, but increased during the second and third trimester until term. At 37 weeks, the plasma viscosity value exceeded the non-pregnant value, the difference being statistically significant. The increase in plasma viscosity during the second and third trimester of pregnancy was determined by the rise in fibrinogen concentration, which overruled the plasma viscosity lowering influence of the falling total serum protein concentration [24].

There are also physiological changes in plasma viscosity during exercise and training [38]. Plasma viscosity increases during exercise due to both plasma concentration and enrichment in protein content, and then decreases in post exercise due to hemodilution, and, in the case of regular exercise, further decreases proportionally to the increase in aerobic working capacity. This training-induced decrease in plasma viscosity may compensate for raised hematocrit in elite athletes trained in altitude [142].

Without any exercise, fluid shifts may be simply due to position changes from recumbent or sitting to supine, and may often dramatically change plasma viscosity due to changes in water content of plasma $[30,38]$.

Proteins are the other determinant of the viscosity of plasma. Proteins that markedly influence plasma viscosity are less spheroid and have a higher molecular weight: fibrinogen, lipoproteins, $\alpha 2$ macroglobulin, and immunoglobulins. We report in our previous review two predictive equations for plasma viscosity calculated from plasma protein content [24]. The first one was presented by Jung and Kiesewetter at the VIIth European Conference on Clinical Haemorheology, Southampton (England) in July 1991 [97]. After studying 2821 subjects included in the Aachen study, they found the following formula:

plasma viscosity $=0.791+0.017 * \alpha 2$ macroglobulin $+0.133 *$ Fibrinogen $+0.017 * \operatorname{IgM}+$ $0.11 *$ cholesterol.

Another was proposed by Eterovic and coworkers in 1995 [24] on a smaller sample of 120 subjects including 30 controls. These authors give the following equation:

plasma viscosity $=1.352+0.0167 \mathrm{CHOL}(\mathrm{mmol})+0.0285 \mathrm{Fib}(\mathrm{g} / \mathrm{L})+0.0054 \mathrm{TG}(\mathrm{mmol})+0.00318$ Hct -0.03 HDL $(\mathrm{mmol})$. 
In both equations plasma cholesterol levels are one of the stronger determinants, and that could lead to think that cholesterol plays an important role in plasma viscosity. Accordingly, an article on blood rheology after menopause evidences a correlation between plasma viscosity and cholesterol levels [24]. Even after multivariate analysis, a rise of $100 \mathrm{mg} / \mathrm{dL}$ in serum cholesterol increases on the average plasma viscosity by $0.05 \mathrm{mPa}$.s. However, the contribution of LDL and HDL cholesterol to plasma viscosity seems quite limited [85] and this effect is likely to be rather explained by lipoproteins than cholesterol itself $[112,180]$. This has been nicely demonstrated by experiments that increased the cholesterol content of plasma, showing no effect of added cholesterol on plasma viscosity [132]. Similarly, adding to blood suspensions fat emulsion currently used for parenteral nutrition was shown to have minimal effect on plasma viscosity at usual doses [24] although at much higher doses it resulted in plasma hyperviscosity. As we will show later, triglycerides have a major effect on blood viscosity with experimentally obvious circulatory effects [24] but this effect is explained by red cell aggregation and is not due to changes in plasma viscosity.

Actually, fibrinogen having the largest molecular size $(340 \mathrm{kD})$ is in physiological conditions the main determinant. Hormone replacement therapy in postmenopausal women decreases plasma viscosity via a decrease in fibrinogen [24].

By contrast, albumin which has a low molecular size $(65 \mathrm{kD})$ exerts minimal effect.

Alpha macroglobulins are plasma proteins whose main function is to inactivate proteinases, protecting the tissues from the action of these enzymes. They are an important determinant of plasma viscosity has demonstrated by experimental infusion of monofluorophosphate to blood suspensions in rats. This treatment induces a parallel increase in alpha macroglobulins and plasma viscosity, without affecting red cell deformability [57].

Immunoglobulins increase plasma viscosity proportionally to their concentration in plasma [54, $105]$.

An autoregulatory loop for plasma viscosity, involving a control of protein synthesis by the liver may be another viscoregulatory homeostatic loop, as reported by W Reinhart. Viscosity modulates gene transcription for albumin and apolipoproteins in cultured hepatocytes [154].

In a pathologic situation with important metabolic disturbances such as type I diabetic nephropathy plasma viscosity was positively correlated with plasma concentrations of fibrinogen and haptoglobin [220].

Oxidative stress may also influence plasma viscosity, although the mechanism for this remains unclear. In hypothyroidism, plasma viscosity was found to be increased parallel to increased markers of oxidative stress. After L-thyroxine replacement therapy resulting into return to an euthyroid state, plasma viscosity and thiobarbituric acid reactive substances (TBARS) decreased, and the authors found a significant correlation between plasma cholesterol and viscosity. Increased plasma viscosity in hypothyroidism thus seems to be related to a deleterious lipid profile, but also perhaps to oxidant stress [24].

Obstructive sleep apnea syndrome (OSAS), a pathologic situation that markedly impairs endothelial dysfunction and is at risk for atherosclerosis and cardiovascular disorders, is usually associated with increased plasma viscosity [83].

In some clinical conditions plasma protein content is markedly disturbed, and plasma becomes a non-newtonian fluid. This has been for example described in patients suffering from cancer at advanced stages [24]. Very high viscosity of plasma at low shear is such patients has been reported to be associated with a poor prognosis. We discussed this issue in our previous review [24].

Plasma viscosity is also a marker of insulin sensitivity, so that when this parameter is lowered it increases [35]. The correction of insulin resistance with exercise training at low intensity targeted on the level of maximal lipid oxidation reverses this abnormality $[26,38]$. 


\section{Regulation of hematocrit}

Hematocrit is by far the major determinant of blood viscosity $[46,170]$. It is classically said that arterial hematocrit is lower than venous hematocrit, but this difference is not always evidenced in recent studies, and interestingly the correlation between venous and arterials hematocrits is very high $(r=0.990)$ [4]. In microcirculation it is markedly decreased due to plasma skimming and to the Fahraeus Effect (see below) and thus can be as low as $20 \%$ of venous hematocrit or even lower [115]. In addition, changes in body position and exercise markedly modify hematocrit [205].

Despite classical literature showing that high hematocrit impairs blood flow [79, 130] and increases the risk for hypertension $[66,86]$ and atherothrombotic events $[75,153,218]$, the team of M. Intaglietta has demonstrated over the last decade that moderate increases in hematocrit do exactly the opposite. They induce vasodilation via shear-induced NO release by endothelial cells, resulting in decreased resistance and increased flow $[164,165]$.

Notwithstanding this biphasic effect, hematocrit should not increase above an optimal value that results into the optimal oxygen supply to tissue. This optimal hematocrit has been the subject of a large literature that has been recently summarized by Walter Reinhart [155].

The most obvious mechanism governing hematocrit is the lifespan of red cells. Decreased red cell lifespan resulting from eryptosis in various diseases may induce anemia [21]. Eryptotic erythrocytes exhibit a host of morphological alterations including volume reduction, membrane blobbing and breakdown of the membrane phospholipid asymmetry resulting in phosphatidylserine externalization which, in turn, mediates their phagocytic recognition and clearance from the circulation by the spleen, thus shortening their lifespan, resulting into anemia [149].

The late Leopold Dintenfass (1921-1990), a pioneer of hemorheology, postulated in the middle of the XXth century that there were « viscoreceptors » that triggered a hematocrit lowering mechanism in response to an increase in blood viscosity [58]. This mechanism was further elucidated by the team of Walter Reinhardt who demonstrated that plasma viscosity was able to inhibit erythropoietin release by the kidney [184]. This mechanism is likely to explain lower values of hematocrit in situations where one or several viscosity factors are increased, thus maintaining a normal value of whole blood viscosity [193]. This very frequent situation has been termed "covertly" abnormal blood and is likely to have pathophysiological relevance despite an apparently normal value of whole blood viscosity rheology [174]. For example, we clearly evidenced this mechanism of viscoregulation in diabetes and in ovarian cancer [24].

Another hormone that may modulate hematocrit via its effects on fluid homeostasis is endothelin-1. This hormone is a potent vasoconstrictor that decreases cardiac output and increases hematocrit and arterial pressure. Its effects on hematocrit are independent of splenic contraction or renal losses and are due to an increased loss of plasma volume to the interstitial space without affecting RBC volume [219].

There is an intriguing issue concerning hematocrit in obesity. Several teams have found that abdominal fat increases blood viscosity due to a rise in hematocrit, even within a normal range of body weight [39].

\section{Red cell deformability and its regulation}

In physiological conditions red bloods cells possess a remarkable ability to undergo large shape modifications that allow them to pass through narrow capillaries, whose diameter is twofold or even more smaller than their own one. This ability to get deformed allows also them to elongate in flow, and this deformation is thus an important determinant of blood viscosity that at high rates of shear can be 
modelized as the viscosity of a Newtonian fluid $[128,185]$. This red cell deformation in flow has been studied by microscopic flow visualization and was classically described as "fluid drop-like adaptation" associated to a "tank treading" motion of the membrane around the cytoplasm [173]. However, this evidence was obtained with experiments in nonphysiologic suspending media. Recently, new experimental approaches [198] have shown that for normal values of plasma viscosity this deformation of red cell in flow is not associated with tank treading and is characterized by a large variety of cell shape alterations for any given flow condition [108]. More precisely, when the shear rate increases above $10 \mathrm{~s}^{-1}$ erythrocytes which exhibited in resting conditions a shape of typical discocytes gradually adopted an aspect of cup-shaped stomatocytes, and then, whith a further increase in shear rate, the form of highly deformed polylobed cells. This variety of shapes is influenced by the surrounding milieu and by hematocrit. It is assumed that it can have an important physiological relevance [108]. Obviously, the classical calculation of a parameter of shear-dependent red cell elongation such as Dintenfass's "Tk" [58] or Quemada's "k" or syllectometric index of flexibility provided by the Laser-assisted Optical Rotational Cell Analyzer (LORCA) gives only an average evaluation of a far more complex phenomenon whose versatility requires further studies.

Presumably, the deformability of erythrocyte entering a narrow channel and the deformability of erythrocyte deforming in flow in a large vessel are different, although closely related, properties and do not rely on the same cellular mechanism. Some discrepancies according to the methods can be found in the literature.

Classical experiments using artificially rigidified red cells demonstrate that a decrease in red cell deformability can markedly impair tissue perfusion [47]. Examples of very rigid red cells that are close to this experimental model exist in human pathology in sickle cell disease [51]. In this case stiffened erythrocytes are able to induce vessel occlusion. However, most of the time, modifications of red cell deformability are less important, and cells are still able to deform to some extent and to transit in the microcirculation, but they are likely to pass only in the largest channels and thus to induce a capillary maldistribution of flow [6, 109].

There is a large literature reporting the effects of many factors on red cell deformability, that was mostly published in the last 20 years of the XXth century. Our preceding review gives an overview of this research. However, all this literature was written before the emergence of the concept of eryptosis and thus does not clearly separate reversible and irreversible red cell rigidification, the latter being most of the time associated with eryptosis [147].

A host of pathophysiological situations have been shown to stimulate eryptosis, and they are all situations where red cell deformability has been reported to be impaired: dehydration, hypoxia, iron deficiency, malignancy, metabolic syndrome, diabetes mellitus, phosphate depletion, hemolytic anemia, heart failure, renal insufficiency, hemolytic uremic syndrome, sepsis, mycoplasma infection, malaria, sickle cell disease, etc.... On the opposite, there is a wide list of inhibitors of eryptosis including adenosine, caffeine, catecholamines (isoproterenol), erythropoietin, resveratrol, urea, vitamin $\mathrm{E}$, etc... that are also acting on erythrocyte rheology [107].

Presumably all the classical literature on red cell deformability should be revisited under the light of this important concept. For example, physiological reversible red cell rigidification during exercise [38] has probably a completely different meaning compared to pathologic alterations of red cells observed in metabolic diseases such as diabetes [90, 203].

Obviously, the major regulator of red cell deformability is the clearance of rigid red cells by the spleen. During their lifespan, circulating RBC are frequently checked for their deformability. This mechanical quality control operates essentially in the human spleen. RBC unable to squeeze though narrow splenic slits are retained and cleared from blood circulation [60, 125].

Besides, there are many influences that can modify red cell deformability. We try to summarize them below. Classically, the most important modifier of erythrocyte deformability was physicochemical 
characteristics of the surrounding milieu [103]. Both $\mathrm{pH}$ and osmolality exerted a biphasic influence that can be represented with an "u shaped curve", the deformability being optimal in a physiological range and impaired beyond quite narrow physiological limits. This effect was assumed to be associated with decreased lifespan and accelerated trapping from the circulation [67]. An environment containing proteins (albumin) was also required in order to avoid shape alterations of the red cells, since albumin has the capacity to prevent and even to reverse echinocytosis [157].

Some studies have also been devoted to divalent cations. For example, magnesium has been shown to protect erythrocytes from in vitro experimental rigidification by several procedures [61]. Zinc, which in vitro increases the deformability of artificially hardened red cells [28], is frequently low in the serum of sportsmen, this situation reflecting some degree of deficiency. Sportsmen with low serum zinc have a higher blood viscosity and an impairment in erythrocyte deformability $[24,30,38]$ which is associated with a decrease in performance. Experimentally, a double blind randomized trial of oral zinc supply in healthy volunteers improves blood viscosity $[24,30,38]$ while the effects on performance are not significant. Zinc seems also to reduce erythrocyte aggregation both in vitro and in vivo [24]. More recently, in contrast with these findings, it was shown that zinc can promote eryptosis [96].

Iron is probably the most studied and the best-known trace element. This interest is largely explained by the frequency of iron deficient states and by the possibility of treating them with iron supplementations. Almost 30 to $40 \%$ of the total body iron is stored under the form of ferritin and hemosiderin, while a lower amount is stored as transferrin [53]. Therefore, serum ferritin is a reliable marker of iron stores. Although a high ferritin value cannot rule out the existence of an iron-deficiency, a low ferritin value is highly specific of a deficiency. Experimental studies in iron-deficient rats have evidenced a lower erythrocyte flexibility that seemed to be related at least in part to a lower hemoglobin content of erythrocytes [24]. Athletes with low plasma ferritin exhibit a higher blood viscosity, a higher plasma viscosity, and a higher red cell aggregability when compared to sportsmen with normal plasma ferritin. By contrast, there is no difference in either hematocrit or erythrocyte rigidity between these two subgroups [30]. In addition, it should be noted that $\mathrm{Fe}^{++}$deteriorates structure of $\mathrm{RBC}$ membranes [49] and thus induces more rouleaux networks. It is now established that $\mathrm{Fe}^{++}$triggers eryptosis [147]. This may explain why RBC deformability is significantly decreased in hemochromatosis [122]. However, on the short term, the effect of $\mathrm{Fe}^{++}$on $\mathrm{RBC}$ rigidity is not easy to evidence. No differences in $\mathrm{RBC}$ deformability or RBC aggregation/aggregability were detected when healthy RBC were incubated in vitro with varying dose of $\mathrm{FeCl}_{3}$.

$\mathrm{N}$-methyl D-aspartate (NMDA) receptors are important targets of divalent cations and explain most of their effects in various tissues. Such receptors have been identified on the red cell membrane and contribute to intracellular calcium regulation in erythrocytes [119] but their activation has no influence on rheological properties of red cells [156]. This report suggests that the action of these various cations on deformability is not primarily mediated by NMDA receptors. However, it has been shown that RBCs of sickle cell disease patients exhibit abnormally high abundance of NMDA receptors mediating excessive calcium uptake, and probably the further cascade of cell-damaging events that include a red cell rigidification [81]. In addition, Unal [202] recently reported that memantine, an NMDA receptor antagonist altered the erythrocyte deformability in the rats. This may suggest that although activation of NMDA receptors has no effect on the deformability of normal red cells, the inactivation of these receptors has such an effect, whose relevance remains to be more precisely established.

Oxidant stress rigidifies the red cell [146] and is also known to induce eryptosis [147]. This can be a typical example of the ambiguity of red cell deformability, which can be moderately and reversibly impaired in some physiological situation and irreversibly damaged, according to the importance of the stress. For example, during the early postburn period, Bekyarova and coworkers have evidenced a reduced erythrocyte deformability related to activated lipid peroxidation [17]. Despite the paucity of literature on eryptosis in burn, the host of red cell shape alterations described in that situation is very 
likely to reflect an increase in programmed cell death [80]. Therefore, in this situation of major oxidant stress red cell rigidification is likely to reflect eryptosis. This increased rate of eryptosis is perhaps a protective mechanism against exposure to older RBCs which is now evidenced as independently associated with an increased risk of death [93, 141].

Raised oxidant stress during exercise is a purely physiological event but can be very important and become harmful, trained athletes being protected from its deleterious effects. Accordingly, both in rats [178] and in humans [179] exercise-induced oxidative stress impairs erythrocyte deformability in sedentary but not exercise-trained individuals.

The antioxidants Vitamin E [104, 138], alpha-tocopherol [217] alpha-tocotrienol [16], fish oil, as well as dietary tea catechins [131] decrease RBC rigidity.

To undergo deformation, the red cell needs energy. Therefore, the depletion of its energetic stores has a major effect on its deformability. It occurs when red cells are conserved in vitro, and is characterized by a gradual temperature- and time-dependent decrease of glucose and ATP, while there is at the same time an increase of lactate and lactate dehydrogenase. Meanwhile, an erythrocyte swelling and echinocytic shape transformation, which was also time- and temperature-dependent, occurs, and is correlated with an increase in red cell rigidity that can be measured with blood viscosity at high shear rate. Echinocytosis is partially reversible when erythrocytes are suspended in buffer containing $0.2 \%$ albumin [158]. However, it is clear that glucose depletion of erythrocytes triggers eryptosis [107].

The issue of hyperglycemia has been extensively studied. On the short-term hyperglycemia does not markedly impair blood rheology unless extremely high concentrations (hundreds of mmol/l) which are never found in human disease are applied [87]. However, raised intracellular sorbitol resulting from chronic hyperglycemia may impair red cell deformability [162] but the experimental concentrations of sorbitol used in those studies are unlikely to be relevant to human disease. In fact, diabetes is clearly a situation in which blood rheology is altered $[175,186]$ although these alterations are quite moderate when the disease is well equilibrated $[24,190]$. Nevertheless, such situations of "covertly abnormal" blood rheology [174] are likely to induce some microcirculatory disturbances. In addition, transient hyperglycemic spikes [24] raising up to $15.6 \mathrm{mmol}$ induce alterations in red cell aggregation, plasma viscosity, fibrinogen and albumin which are associated with a measurable decrease in transcutaneous oxygen partial pressure determination $\left(\mathrm{TCPO}_{2}\right)$. Recently, Shin [181] carefully investigated the in vitro effects of blood glucose levels on erythrocytes from diabetic patients. They observed that, when glucose concentrations increase, erythrocytes aggregation also increases, and deformability is reduced. This seems to occur in diabetic patients but not in healthy subjects. The shape of the red cells is modified, with a significant increase in the perimeter to area ratio which explains at least in part the decrease in deformability.

Interestingly, carbohydrate regular intake is also a determinant of red cell rigidity, as evidenced in a study by Varlet-Marie and coworkers in trained athletes. In this study both caloric (and carbohydrate) intake are correlated with increased RBC rigidity [206].

Blood lipid concentrations are strong statistical determinants of blood viscosity factors. Presumably, lipid content of the red cell membrane can influence its fluidity. Correlations between serum cholesterol and $\mathrm{RBC}$ rigidity have been found in many studies [27]. Reducing erythrocyte membrane cholesterol and simvastatin both increase cell deformability resulting in increased ATP release [70]. On the opposite polyunsaturated fatty acids of the omega 3 family ( $\omega 3$ PUFA) exert important physiological effects by improving RBC flexibility either in healthy volunteers [78, 98, 110] or in patients [196]. A study of the hemorheological changes during postprandial lipemia shows that lipids and fibrinogen may act synergistically so that the effect of large triglyceride- rich lipoproteins is potentiated by fibrinogen [177].

Correlations found between improved RBC deformability and the ability to oxidize at exercise more lipids may be due to effects of endurance training on lipid oxidation which may in turn modify both lipid metabolism and free radical generation, thus influencing RBC rheology [36]. 
Another molecule that physiologically circulates in blood and has an effect on red cells is lactate [38]. While in vitro increased concentrations of this metabolite decrease red cell deformability, a rigidification of red cells during exercise is only found when blood lactate concentrations are higher than $4 \mathrm{mmol} / \mathrm{L}$, i.e., the onset of acidosis [29]. In fact, in endurance trained athletes this effect is no longer found, and, on the opposite, lactate may exert specific beneficial effects on red cell deformability [52]. This specific training-induced pattern of response to lactate may provide an alternative explanation to the exercise-induced arterial hypoxemia that occurs in such athletes.

Ketone bodies are another fuel that is largely used by tissues in some situations like starvation. Situations associated with high concentrations of ketone bodies are also likely to modify erythrocyte rheology, due to alterations in membrane properties, as evidenced by Peyreigne [24] in the case of a short-term ketogenetic diet.

One of the most important substances that interact with the red cell, and can be released by it, is surely NO [183]. Although the major source of NO is the endothelium, NO can also be produced by intraluminal sources, particularly erythrocytes, since they possess functional NO synthesizing mechanisms [45]. It is well established nowadays that NOS (nitrous oxide system) activation and NO export can be induced in the red cell by mechanical stress and NO is then released in very close proximity to vessel walls [201]. NO protects erythrocytes from sub-hemolytic mechanical damage [12]. Even more importantly, NO increases RBC deformability, as demonstrated by M Bor-Kuçukatay [23] who reported that NOS inhibitors significantly reduced RBC deformability above a threshold concentration, whereas NO donors increased deformability at optimal concentrations. This potent regulator of vascular tone is also a major regulator of blood rheology. NO donors, as well as the NO precursor l-arginine and the potassium blocker tetraethyl ammonium, were able to reverse the effects of NOS inhibitors. This important paper provides a strong evidence of physiological regulatory role of NO on RBC deformability. It has been also shown that nitric oxide from polymorphonuclear leukocytes can directly activate red blood cell deformability [101]. Effects of NO on the red cell depend on the concentration, as studied by Mesquita [166]. When blood was exposed to NO $10^{-7} \mathrm{M}$ erythrocyte deformability increases and in presence of $\mathrm{NO} 10^{-5} \mathrm{M}$ lipid fluidity and p50 decrease. When blood was exposed to NO $10^{-3} \mathrm{M}$ methemoglobin concentration increased erythrocyte deformability and p50 decrease but membrane fluidity and lipid peroxidation were similar to control. SpermineNONOate also increased erythrocyte deformability due to changes on $\mathrm{RBC}$ membrane, resulting in and oxygen carrying properties [167]. Older RBC are characterized by diminished internal NO synthesis and are also less sensitive to external NO, and this can of course explain at least in part why older erythrocytes become less deformable [124]. Interestingly, NO is a protector of the red cell via demonstrated anti-eryptotic effects [133] that may further prevent a loss of deformability.

This involvement of NO in the regulation of red cell deformability has some interesting applications in human pathology. For example, hypoargininemia during Plasmodium falciparum malaria has been reported to impair NO production and reduce RBC deformability, particularly at febrile temperature [161]. In sickle cell anemia the stimulating effect of NO on RBC deformability is blunted by oxidative stress which appears to impair the effectiveness of RBC-NOS produced NO [76, 127]. In experimental hypertension, an impairment of the NO effect on RBC deformability has been described [24].

A large body of evidence indicates important roles for purinergic receptors in RBCs. Purinergic signaling involves the activation of cell surface $\mathrm{P} 1$ and $\mathrm{P} 2$ receptors by extracellular nucleosides and nucleotides such as adenosine and adenosine triphosphate (ATP), respectively. P2 receptors comprise $\mathrm{P} 2 \mathrm{X}$ and $\mathrm{P} 2 \mathrm{Y}$ receptors. $\mathrm{P} 2$ receptor activation stimulates a number of signaling pathways in progenitor $\mathrm{RBCs}$ resulting in microparticle release, reactive oxygen species formation, and apoptosis. Likewise, activation of $\mathrm{P} 2$ receptors in mature $\mathrm{RBCs}$ stimulates signaling pathways mediating volume regulation, eicosanoid release, phosphatidylserine exposure, hemolysis, impaired ATP release, and susceptibility or resistance to infection [187]. Adenosine protects against eryptosis by a mechanism presumably 
effective downstream of protein kinase $\mathrm{C}$. The effect may participate in the maintenance of microcirculation in ischemic tissue [134]. It is known since a long time that red cells are able to release ATP and ADP [3]. ATP and ADP are apparently continuously released from red cells and then broken down to adenosine which reenters the erythrocytes. More recently it has been established that RBCs can release ATP in response to hypoxia and hypercapnia, but also exposure to mechanical deformation, $\beta$-adrenoceptor agonists, prostacyclin analogues, reduced $\mathrm{O}_{2}$ tension, acidosis or swelling. Sprague et al. [189] proposed that the increased shear stress inside narrower channels causes the RBCs to deform, and that the deformation triggers release of ATP. This ATP binds to purinergic P2 sites on endothelial cells leading to the release of NO and PGI2 [126]. Caffeine enhances ATP release from erythrocytes, most likely due to its effect on intracellular levels of cyclic adenosine monophosphate (cAMP). The level of intracellular ATP is crucial for maintaining the function and structural integrity of circulating RBCs. ATP depletion, in turn, sensitize the erythrocytes for the eryptotic effects of $\mathrm{Ca}^{2+}$ [147]. The A3 adenosine receptor antagonist reversine (2-(4-morpholinoanilino)-6-cyclohexylaminopurine) is known to influence cellular differentiation, to inhibit cell proliferation, to induce cell-cycle arrest, to trigger apoptosis, and to cause cell swelling. However, due to the fact that red cells are lacking mitochondria, it has been shown to be a powerful inhibitor of cell membrane scrambling following energy depletion, $\mathrm{Ca}^{2+}$ loading and oxidative stress, and thus to prevent eryptosis [88]. It has been suggested that sensing of low blood $\mathrm{O}_{2}$ content may involve ATP release from $\mathrm{RBCs}$, leading to stimulation of sensory aortic body neurons via $\mathrm{P} 2 \mathrm{X} 2 / 3$ receptors [143]. The ATP degradation product, ADP, inhibits ATP release by a negative feedback pathway mediated by P2Y13 receptors on human RBCs [211]. Of course, all these interactions are likely to be reflected by alterations in red cell rheology but literature on this topic is relatively scarce. It was reported in the early eighties by I. Juhan et al. that ADP released by rigid red cells decreased the deformability of RBCs [90]. ADP release from red cells is lower in middle-aged than young healthy volunteers and if they are experimentally fed with fish oil red cell deformability increases parallel to a decrease in ADP release by 50\% [98].

Therefore, red cell deformability and purinergic signaling clearly appear to be closely connected mechanisms. Rigidification of red cells inhibits ATP release, which is in turn increased when red cells are made more deformable by hydroxyurea or the cholesterol-lowering drug simvastatin [41]. In turn, rigid red cells release ADP which blunts ATP release (probably in order to maintain energy stores). This mechanism is likely to induce a self-potenting loop increasing red cell rigidification. In addition, when RBC are well deformable and release ATP, they induce more NO production by the vessel wall which is likely to promote both vasodilation and enhanced RBC deformability [116].

There have been many reports of hormones and other chemical messengers that have specific receptors on erythrocytes. These include immunoglobulins (IgG), complement [215], and lectins [192].

Hormones like insulin bind on the red cell membrane and activate intracellular pathways, with an effect on red cell deformability that was evidenced in the eighties $[40,64,90]$ and is still found in recent studies [127]. It seems now well established that insulin really influences red cell rheology via direct effects on the membrane [40] that include alterations of the lipid membrane bilayer composition and microviscosity, together with changes in membrane $\mathrm{Na} / \mathrm{K}$ ATPase function [151]. According to the situation, the effects of insulin on red cell deformability may be different. For instance, very high supraphysiological levels in vitro decreased red cell deformability [24] as recently confirmed by Linde during insulin clamp experiments in which an increase in RBC rigidity in hypertensives was observed [113]. Another important effect of insulin was reported by Aursnes who showed that ATP concentrations in erythrocytes are fairly correlated with free insulin levels in plasma [24]. Given the above reported effect of ATP on red cell deformability, this effect may have important implications.

The insulin like growth factor I (IGF-I) is an important hormone closely related to insulin, which can bind on its receptors and share some activity with it. IGF-I receptors have been described on the red cell membrane [44]. Relationships between blood viscosity and IGF-I status were therefore investigated 
in athletes by Monnier who reported that values of IGF-I within the upper quintile are associated with an impairment of blood fluidity, possibly due to a direct effect of IGF-I on red cell deformability and aggregability. Among factors of blood viscosity, IGF-I is correlated with red cell rigidity measured with viscometry at high shear rate [24].

Glucagon, a major stress hormone which is involved in the recovery from hypoglycemia and exerts catabolic effects on body protein stores, has been shown to decrease red cell deformability [204]. The opposite was actually reported by Komatsu and coworkers, i.e., intravenously injected glucagon improves red cell deformability (assessed by filterability) and decreases whole blood viscosity in vivo [24]. This effect is associated to an increase in blood flow.

Somatostatin is a tetradecapeptide that circulates in blood [221]. It may induce strong circulatory changes as evidenced by a study showing an increase in peripheral blood flow in man [169]. In addition, it interferes with platelet functions [71]. We reported a strong beneficial effect of this hormone on red cell deformability assessed by several techniques [33].

Among the recently postulated hormonal effects of C-peptide, a pancreatic peptide co-secreted with insulin, an increase in eNOS has been reported, resulting in diabetics in a fluidification of red cell membranes, an increase in renal function, blood flow redistributions and a reduction in NaK ATPase pump function [69].

Actually, using viscometry W. Reinhart concluded that neither C-peptide, Insulin, or Glucagon had any influence on deformability [24].

Thyroid hormones may also act on blood rheology. Receptors for L-triiodothyronine have been evidenced on red cells [2], and impaired red cell deformability in hyperthyroidism (reversible after successful treatment of the disease) has been reported [24].

Acetylcholine via muscarinic cholinergic receptors [194] and nicotinic cholinergic receptors [94] can also bind on red cells and its actions have been recently studied by the team of X. Saldanha who reported that in presence of acetylcholine there is an increase of erythrocyte deformability, and a decrease of erythrocyte aggregation [167]. The team of Alexei Muravyov investigated more thoroughly the signaling pathways involved in this process [129].

On the red cell membrane there are also receptors for the endogenous ligands of benzodiazepine [136], corticotropin-releasing factor (CRF) [55], and prolactin [74]. Most of these chemical messengers have been reported to modify in vitro or in vivo erythrocyte rheology, but, on the whole, data appear to be rather uncomplete and to some extent conflicting.

Presumably, receptor-mediated changes in red cell deformability in response to substances physiologically circulating in blood are likely to be reversible adaptative changes that do not trigger the mechanisms of eryptosis. However, the list of eryptosis-inducing substances presented in the recent review published on this topic by E. Pretorius [147] includes physiological factors (NO, anandamide, iron, adenosine, retinoic acid, zinc), suggesting that eryptosis (and thus an irreversible modification of the red cell leading to its premature death) can be triggered in many physiological conditions, outside of any pathologic context, as an adaptation to a non-pathological situation.

In this respect it is interesting to notice that the endocannabinoid anandamide (Arachidonylethanolamide, AEA), which is known to induce apoptosis in many varieties of nucleated cells, increases red cell cytosolic $\mathrm{Ca}^{2+}$ activity, thus leading to cell shrinkage and cell membrane scrambling of mature erythrocytes and subsequent eryptosis [18].

The pineal gland-derived hormone melatonin has been shown to experimentally decrease red cell deformability, although pinealectomy by itself did not cause any statistically significant change in erythrocyte deformability [24].

The kidney hormone erythropoietin (EPO) is a major regulator of red cell mass and turnover, and for this reason it exerts major effects on several aspects of blood rheology. Some studies in the early nineties described the follow-up of blood viscosity factor during the natural history of chronic renal 
failure. Those studies by our Portuguese colleagues J. Martins-Silva and C. Saldanha and by M. Delamaire are thoroughly reviewed in our preceding paper [24]. Follow up over 18 months of patients treated by hemodialysis evidences a decrease gradual in red cell deformability together with a rise in membrane cholesterol and total phospholipids. After 18 months, there is an increase in phosphatidylcholine/phosphatidyl ethanolamine ratio in the membrane. Hemorheological disturbances (red cells less deformable, increased plasma viscosity) are corrected by rhEPO and kidney transplant. These old studies should be re-interpreted under the light of the current knowledge on eryptosis [107]. EPO has anti-eryptotic properties, but it cannot completely counteract the induction of eryptosis due to its effects on intracellular calcium influx [209].

Among arachidonic acid derivatives, some leukotrienes but not all [24] may impair red cell deformability. Prostaglandin E1 (and iloprost) improve red and white cell filterability in vivo [24, 65]. PGE2 rigidifies red cells and increase their aggregability [25].

RBCs can also release endothelin-1 (ET1) together with endothelial and smooth muscle cells. There are conflicting results about the effects of ET1 on red cell deformability since Sakashita reported that it improves the impaired filterability of RBCs through the activation of protein kinase C [163] while Walter found no effect of it when deformability was assessed with viscometry [210].

Similarly, it is remarkable to notice that, despite the importance of intracellular calcium on red cell rheology, neither parathormone, calcitonin nor Vitamin D3 has any influence of blood rheology [120].

There is a large body of literature on the hemorheological effects of sex hormones. Most of this literature is related to oral contraceptives (OC), a hot topic because of their thrombogenic effects. We previously reviewed it in our precedent review [24]. Briefly, OC users in the late seventies were mostly characterized by a lower red cell deformability and a slightly higher whole blood viscosity despite normal values of plasma viscosity. Hematocrit was also reported to be increased in some studies but not all. The progestin component of the pill was assumed to be responsible for a rise in fibrinogen which explained most of this pattern. Actually, this finding on old progestin compounds of OC pills (mostly 19nortestosterone derivatives), contrasts to some extent with the more recent physiological investigations which evidenced in normally cycling women that estradiol levels were positively correlated to whole blood viscosity, plasma viscosity and fibrinogen, and negatively correlated to red cell deformability. In physiological conditions, therefore, estrogens were likely to impair blood fluidity. On the opposite, progesterone in physiological conditions had the opposite effect, decreasing both fibrinogen and blood viscosity, and increasing red cell deformability, as further indicated by higher values of deformability in the luteal phase. More recent, low dose, compounds are almost devoid of hemorheological sideeffects in contrast to older preparations, but they still induce moderately higher red cell aggregability. Estrogen are also known to increase NO synthesis and release by endothelial cells. Estrogens are likely to be a physiological stimulus for NO since estrogen-response elements have been identified in the promoting region of the gene coding for the endothelial nitric oxide synthase. Moreover, estrogens have been suggested to act more rapidly via membrane receptors, resulting in an increase in cytosolic $\mathrm{Ca}^{++}$in some cells, and to exhibit antioxidant properties which may delay NO clearing from blood [24]. All these mechanisms are likely to improve red cell deformability via NO-mediated mechanisms. However, the hormonal treatment by estrogens (either transcutaneous or oral) has been reported to increase RBC rigidity by increasing membrane rigidity [24]. In vitro $\beta$-estradiol $10^{-5} \mathrm{M}$ decreased erythrocyte aggregation in blood samples of postmenopausal women undergoing hormone therapy, which could prevent high blood viscosity and, consequently, cardiovascular events [24].

Recently a newly discovered hormone, apelin, has also been studied in rats with diabetes and ischemia-reperfusion injury of heart, thus exhibiting an impairment in erythrocyte deformability. It was shown that apeline-13 reversed this loss of deformability [92].

An important regulator axis acting on red cell rheology may be catecholamines, which circulate in blood and act on erythrocyte via specific $\alpha$ - and $\beta$-adrenergic receptors [191] for regulating cell 
volume and ion transport [22]. The first studies in the late eighties by Pfafferott and Volger indicated that in vitro norepinephrine and isoprenaline reduced erythrocyte deformability [24]. More recently, a more complicated picture emerged from the works of Hilario, Saldanha and Martins-Silva who demonstrated in human erythrocytes that although epinephrine is able to induce the formation of echinocytes, it also improves RBC deformability [82]. This is in line with the reported anti-eryptotic effect of catecholamines [106] and with the role of those hormones which are beneficial on the short term for body's adaptation to an unusual stress. In trouts (whose red cells are nucleated) catecholamines induce a dramatic increase in cell volume as a result of an accumulation of sodium and chloride due to activation of an amiloride-sensitive, cAMP-dependent $\mathrm{Na}^{+}-\mathrm{H}^{+}$exchanger allowing $\mathrm{Na}^{+}$to enter in exchange for internal $\mathrm{H}^{+}$. At the same time, red cell deformability is improved (despite the increase in cell volume). Both red cell fluidification and activation of this ionic exchange are likely to be an adaptive response to hypoxia which results in an increased oxygen-carrying capacity of erythrocytes [48]. It seems currently clear that epinephrine improves red cell deformability [82, $137,197]$, presumably via $\beta$-adrenergic receptors while there is apparently no effect of either $\alpha 1-$ and $\alpha 2$-receptor agonists. RBC incubation with epinephrine and isoproterenol resulted in significant changes of deformability, by 10 and $30 \%$, respectively. This is consistent with the other classical effects of catecholamines mediated by $\beta$-adrenergic receptors (vasodilation, increased cardiac output, etc.... that all lead to increase blood flow. The team of Alexei Muravyov has extensively studied the effect of catecholamines on the rheological properties of the human red cell, showing that the effect of these hormones on red cell deformability are mostly under the control of intracellular $\mathrm{Ca}^{2+}$ - regulating pathways [129]. In contrast with this positive effect of catecholamines in physiological conditions on red cell deformability, increased viscosity and decreased erythrocyte deformability were observed in untreated pheochromocytoma [19].

There is a paucity of informations concerning the possible hemorheological effects of cortisol, a major actor of the adaptation to stress. Ursula Windberger has reported that Cushing syndrome in dogs is associated with increased plasma viscosity and erythrocyte aggregation [214].

There are situations associating a lot of disturbances of red cell functions, and the most impressive example is perhaps septic shock. Sepsis is associated with altered metabolism and decreased 2,3bisphosphoglycerate, redistribution of membrane phospholipids, changes in RBC volume, metabolism and hemoglobin's affinity for oxygen, morphology, antioxidant status, intracellular $\mathrm{Ca}^{2+}$ homeostasis, membrane proteins, membrane phospholipid redistribution, clearance and $\mathrm{RBC} \mathrm{O}_{2}$-dependent ATP efflux. RBC autoxidation has been also assumed to worsen the disorder $[14,15]$. Not surprisingly, alterations in RBC rheology, including reduced deformability and increased aggregation, occur early in septic patients and reductions in RBC deformability over time are associated with a poor outcome $[59,145]$. Erythrocyte deformability and NO releasing activity are both decreased as a result of the inflammatory response [182].

Interestingly, there are reports of an effect of prostacyclin and nitric oxide on deformability of RBCs in experimental septic shock in rats [102].

Another example where red cell rigidification is likely to be plurifactorial is the obstructive sleep apnea syndrome (OSAS). This pathologic situation that markedly impairs endothelial dysfunction due to recurrent tissue hypoxia and is at risk for atherosclerosis and cardiovascular disorders [139] is associated with decreased erythrocyte deformability [83]. A decrease in NO bioavailability is observed and may be both a consequence and a worsening factor of the defect in erythrocyte deformability [84].

In this disease there is also increased plasma viscosity and erythrocyte hyperaggregation, as discussed later. Interestingly, the opposite situation, hyperoxia, has no measurable effect on blood rheology, so that its use for donor organ preservation before graft is not likely to induce hemorheologic disturbances [200]. 
In physiology, there are therefore situations that transiently decrease red cell deformability, like acute exercise [24] and also situations that increase it, like exercise training. Interestingly, in transgenic mice overexpressing erythropoietin and thus exhibiting a higher hematocrit, there is an increase in RBC flexibility, presumably linked to increased plasma NO levels, so that whole-blood viscosity was maintained at a normal level [208]. This is another mechanism of "viscoregulation" beside the above-reported regulation of EPO release by blood viscosity, which decreases hematocrit.

\section{Red cell aggregation and its regulation}

Another major aspect of blood rheology is red cell aggregation which has generated considerable interest over the last 25 years. This property is the ability of RBCs to aggregate and to form two- and three-dimensional structures. Despite some remaining controversies, our knowledge of this phenomenon has markedly improved.

In pathology, increased red cell aggregation is almost always associated with situations of impaired blood flow and increased peripheral resistance, suggesting that this phenomenon is rather deleterious for tissue perfusion. This can be explained by the effect of increased aggregation in the postcapillary venules that results in an increase in postcapillary resistance and a slowing of capillary blood flow [20,42], and also by disturbed disaggregating mechanisms in pathological conditions, due to abnormal plasma composition or RBC surface properties as discussed below. Accordingly, $\mathrm{O}_{2}$ release from RBCs is inhibited by RBC aggregation [24] and experimentally induced hyperaggregation of red cells decreases in RBC arteriolar velocity and impairs flow distribution in a capillary network [207]. However, classical experiments evidenced other effects of aggregation that were likely to promote rather than impede vascular blood flow. Red cell aggregation promotes the Fåhraeus Effect, i.e. the reduction of vessel hematocrit with reducing vessel diameter. It also promotes plasma skimming and decreased microvascular hematocrit [72]. The Fåhraeus-Lindqvist Effect (decrease of viscosity in narrow vessels due to a longitudinal disposition of red cells that offer less resistance to flow) is another important consequence of red cell aggregation [73]. In addition, red cell aggregation was shown to promote the migration of white cells at the periphery of the vessel (Fåhraeus-Vejlens Effect) and thus facilitate their margination outside of the vessel lumina $[1,140]$.

An important contribution to our understanding of the circulatory effects of red cell aggregation is due to the works of the late Oguz Baskurt who demonstrated that RBC aggregation can reduce frictional resistance via lowering hematocrit and hence viscosity in the near-wall region, thereby resulting in lower wall shear stress. This lower shear stress results in turn in a lower NO synthesis, and thus inhibits vasodilatation and increases peripheral resistance [13].

Presumably, physiological increases in red cell aggregation like those observed during pregnancy [150] have not the same meaning as those found in pathologic states. In peripheral occlusive arterial disease there is a negative correlation between the extent of red cell aggregation and tissue oxygenation as assessed with $\mathrm{TCPO}_{2}$, showing that aggregation is associated with lower oxygen supply to tissues [61-63].

O. Baskurt and H.J. Meiselman, who have been the authors of most of the major research works on red cell aggregation over the last years, have published several important reviews $[7,9,10]$ that can serve as references. Therefore, in this chapter we will mostly develop the regulatory aspects that are the purpose of our review.

The exact mechanism of red cell aggregation is still controversial, since two opposite theories are currently proposed: the bridging model and the depletion model. In the bridging model, RBC aggregation is assumed to result from the binding of large macromolecules, such as plasma proteins, sticking cells to each other. By contrast, the depletion model assumes that RBC aggregation occurs 
because of a relative depletion near the cell surface leading to an osmotic gradient which induces an attractive force. Those two theories are almost totally opposite and thus difficult to reconcile [124]. Notwithstanding, it is clear that what we know about the mechanisms of red cell aggregation can be described in two separate chapters: the role of red cell factors and the role of plasma factors.

a) The cell-specific factors

Surface properties of the red cells can significantly influence the aggregation process: when washed and re-suspended in a defined polymer or protein solution, differences between healthy donors and between young and old RBC have been demonstrated. It has been shown that reducing the surface charge density of RBC by enzymatic treatments increases their aggregation in standard aggregating media [152].

The energetic status of the red cell is important for a physiological aggregation. Reinhart and coworkers have reported that metabolic depletion for $48 \mathrm{~h}$ leads to RBC swelling and a reversible echinocytic shape transformation, and that such ATP-depleted, but normally shaped RBCs had a decreased aggregability [159].

RBC deformability is an important cellular property for aggregation since cells must change their shape to form parallel membrane surfaces in rouleaux. The properties of the glycocalyx on the exterior of the RBC membrane are also important determinants of aggregation behavior. In sickle cell disease RBC aggregation and deformability are negatively correlated with each other [51]. The same has been observed in patients with hemoglobin C disease: low RBC aggregation index and high RBC aggregates strength, with elevated blood viscosity and decreased RBC deformability [111]. Presumably morphology and deformability of the cells can impair their interaction. In women taking oral contraceptives, we observed that aspirin impaired red cell deformability and that this change was negatively correlated with red cell aggregation [24].

Osmolality, another factor that markedly modifies the red cell shape, also increases red cell aggregability [168].

Inflammatory status has a major role on red cell aggregation as mostly developed below when we will discuss the role of plasma factors. However, it is clear that enhanced aggregation in cases of inflammation or infection cannot solely be explained by increased levels of acute phase reactants, since cellular properties of RBC are also altered in severe infectious and inflammatory diseases [212].

OSAS, a pathologic situation that markedly impairs endothelial dysfunction and is at risk for atherosclerosis and cardiovascular disorders, is usually associated with increased erythrocyte aggregation [195] together with increased oxidative damage to the red cell membrane proteins [83].

Nitric oxide, that is involved in $\mathrm{RBC}$ rigidity, also influences $\mathrm{RBC}$ aggregation. Incubation of $\mathrm{RBC}$ from hypertensive and control animals with NO donor, sodium nitroprusside (10-1000 microM) for 60 minutes resulted in a dose-dependent decrease in RBC aggregation [24].

It is interesting to indicate that low-shear apparent viscosity and related indexes may not always reflect changes of RBC aggregation associated to disturbed cellular properties. Therefore, in situations associating alterations of RBC geometry and/or deformability, low-shear viscometry should not be the sole measurement technique used to assess RBC aggregation [7].

b) The plasma factors

On the whole, the best known humoral regulators of red cell aggregation are probably proteins [24]. The plasma concentration of molecules characterized by a high-molecular weight plays a crucial role. Fibrinogen, as the major determinant of red cell aggregation, has been widely investigated. There is an almost linear relationship between aggregate size and plasma fibrinogen concentration. The plasma substitution by physiological solution or albumin showed the role of albumin on dissociation shear rates. This protective role of albumin is likely to result from its tertiary molecular structure, which can result in a too little size for inducing bridging among red cells, while when albumin has been heated it becomes polymeric and increases aggregation. Albumin properties were altered by heating 
at $56-60^{\circ} \mathrm{C}$. In presence of immunoglobulins, the role of albumin appeared to be complex, depending on the albumin/globulin ratio.

Friederichs investigated the influence of "acute phase proteins" on increased erythrocyte aggregation in infectious diseases in 208 blood samples obtained from 132 children with different pathologies [24]. Aggregate formation was shown to be correlated with the concentration of most of the acute phase proteins of the plasma, mostly fibrinogen.

The aggregate formation of erythrocytes was more sensitively influenced by an increased concentration of the most important acute phase proteins than the erythrocyte sedimentation rate. A distinct correlation of red cell aggregation and the fibrinogen concentration was found.

We suggest, that the measurement of red cell aggregation is an appropriate method to describe the increase in the concentrations of the most important acute phase proteins, especially fibrinogen, during infectious diseases.

Lipoproteins also exhibit strong correlations with rheologic factors, as evidenced on some large samples. In fact, $28 \%$ of the variance of blood viscosity at low shear rate is likely to be explained by serum lipoprotein levels, with an opposite effect of low-density and high-density lipoprotein [24]. Postprandial plasma triglyceride levels correlated significantly with rouleaux formation rate [50]. I. Cicha measured rouleaux formation rate in $70 \%$ autologous plasma (with $30 \%$ phosphate-buffered saline, PBS) or $1 \mathrm{~g} / \mathrm{dL}$ dextran T70 solution (with $4 \mathrm{~g} / \mathrm{dL}$ bovine serum albumin) and observed a significant increase in rouleaux formation rate of samples with high triglyceride levels, when measured in $70 \%$ autologous plasma, which was no longer significant in dextran T70 containing medium. This finding suggests that the alteration of plasma lipid levels as well as possible changes in the cell membrane lipid composition lead to enhanced RBC aggregation [24]. However, in hyperlipidemic patients the kinetics of rouleaux formation is correlated with markers of the phase (IgG, glycoprotein, albumin) [213].

In many situations the importance of those proteins can be easily observed. Increased RBC aggregation in myocardial ischemia and infarction, cerebral ischemia and infarction, peripheral vascular diseases, hypertension, has been repeatedly reported and found to be correlated with fibrinogen. In type I diabetic nephropathy, erythrocyte aggregation was positively correlated with plasma concentrations of fibrinogen and alpha 2-macroglobulin and negatively with plasma albumin concentration [220]. Chronic inflammation found in parodontopathic disorder has a similar effect [24].

Decreasing protein concentrations in plasma also demonstrate their importance in aggregation. Hemodilution in patients undergoing cardiopulmonary bypass surgery, has been shown to result in a decrease by $44 \%$ of the aggregation in parallel to a decrease in plasma concentration of fibrinogen to $55 \%$, of haptoglobin to $85 \%$, ceruloplasmin to $55 \%$, and albumin to $67 \%$. During this study, at baseline, aggregation was correlated only with fibrinogen. During hemodilution, aggregation was correlated to fibrinogen, haptoglobin and ceruloplasmin [77].

Obesity is associated with moderately increased red cell aggregation [188] whose mechanism and pathophysiological relevance remain incompletely understood. We repeatedly reported that fatness by its own, regardless its localization, is associated with increased red cell aggregation [39]. Since adipose tissue releases a lot of biologically active substances, circulating factors are likely to explain this relationship which remains to be more precisely investigated.

Nutritional habits are by their own associated with modified hemorheologic profiles. For instance, we observed in a sample of sedentary subjects a negative correlation between carbohydrate intake and RBC aggregation [206].

Catecholamines seem to increase red cell aggregation, via both $\alpha$ - and $\beta$-adrenergic receptor activation. The exposure of RBCs to epinephrine, and agonists of $\alpha$ - and $\beta$-adrenergic receptors (phenylephrine, clonidine) increased red cell aggregation by 24 to $60 \%$ [129]. 
Prostaglandin E1 significantly decreased RBC aggregation, and prostaglandin E2 had a similar but lesser effect. The drugs with phosphodiesterase inhibitory activity reduced red cell aggregation. It seems likely that a decrease in aggregation is mainly induced by an activation of the adenylyl-cyclasecAMP system, while regulation of red cell deformability is more closely associated with $\mathrm{Ca}^{2+}$ control mechanisms [129].

Studies with erythropoietin evidence a beneficial effect of this hormone which remarkably improves red cell deformability [176] but increases red cell aggregation in chronic kidney disease patients [56]. The recently developed long acting analogue of erythropoietin methoxy polyethylene glycol-epoetin- $\beta$ $\left(\right.$ MIRCERA $^{\circledR}$ ) also induces a dramatic rise in RBC aggregation [89].

Acetylcholine increases red cell deformability and decreases erythrocyte aggregation associated to changes on RBC membrane and oxygen carrying properties [129]. This action is related to an activation of the adenylyl cyclase-cAMP system and a decrease in $\mathrm{Ca}^{2+}$ entry into the RBC [167].

Insulin and glucagon may also modify RBC aggregation but this issue has not been extensively studied [129]. In vitro insulin increases erythrocyte aggregability in rats [38]. Increased red cell aggregability is also statistically associated with insulin resistance measured with a reference technique (the minimal model), independent of insulin levels $[35,32]$.

\section{Conclusive remarks}

Since our preceding review [24] our knowledge of influences exerted by various factors on blood viscosity has markedly expanded. Of course, many issues still remain unclear at this time. But more and more a very complex picture emerges, that of an exquisitely organized system that is finely regulated in connection with mechanisms governing blood flow and distribution.

Some viscoregulatory loops are now described [154] but the picture is probably even more complex, and blood viscosity is able to be modified by a lot of various physiological or pathophysiological conditions in order to generate an adapted response, that may sometimes become inappropriate.

The review above is only an attempt to put together this impressive mass of information, but it will become important to understand the inner logic of these interactions that are complexly organized.

Considerable attention has been given to an endothelium - leukocyte- liver axis, involving polymorphonuclear neutrophils and monocytes that release a host of biologically active substances that may interfere at various levels in the regulation of blood viscosity. Via cytokines like IL-6 they may induce a rise in fibrinogen which increases plasma viscosity and red cell aggregation. Via free radicals and arachidonic acid derivatives they may alter red cell membrane properties and thus modify red cell deformability. Free radicals increase both aggregability and rigidity of the red cells, while proteases mostly increase aggregation. These interactions between white cell activation and red cell rheology have been extensively investigated by the team of O. Baskurt [11], among others, showing that most of the hemorheologic profile of vascular or inflammatory diseases is explained by these white cell red cell interactions. Even more, these processes are likely to be important in body's response to an inflammatory stimulation [1].

However, some integrated responses of the organism, like stress, regulation of energy stores, activation of the growth-hormone IGF axis, involve a hemorheologic response whose relevance is less well understood. The relationship between the size of adipose stores and blood rheology even in normal conditions is also an intriguing finding and some reports suggest that hormones released by the adipose tissue (leptin and adiponectin) have circulatory effects [123]. Reports by several teams of differences in blood rheology according to dietary habits is also an intriguing issue [30, 38].

We recently proposed a working hypothesis based on the "healthy primitive lifestyle paradigm" which assumes that evolution has selected genetic polymorphisms leading to insulin resistance as an 
adaptative strategy to cope with continuous low intensity physical activity and a special alimentation based on lean meat and wild herbs (i.e., moderately high in protein, rich in low glycemic index carbohydrates, and poor in saturated fat). We propose here that this model may help to explain on an evolutionary perspective these apparently inconsistent findings. The pivotal explanation is that the true physiological picture would be that of an individual whose exercise and nutritional habits are close from this lifestyle, both sedentary subjects and trained athletes representing situations on the edge of this model [31]. We recently presented data which suggest that this theoretical background may explain most of the findings that seem difficult to integrate in a logic picture of hemorheologic homeostasis [37]. Therefore, the underlying logic of this extremely complex interactions may be little by little understood, opening new directions of research.

\section{References}

[1] Abbitt KB, Nash GB. Rheological properties of the blood influencing selectin-mediated adhesion of flowing leukocytes. American Journal of Physiology Heart and Circulatory Physiology. 2003;285:H229-40.

[2] Angel RC, Botta JA, Farias RN. High affinity L-triiodothyronine binding to right-side-out and inside-out vesicles from rat and human erythrocyte membrane. Journal of Biological Chemistry. 1989;264:19143-6.

[3] Aursnes I, Gjesdal K, Abildgaard U. Platelet aggregation induced by ADP from un sheared erythrocytes at physiological $\mathrm{Ca}^{++}$-concentration. British Journal of Haematology. 1981;47(1):149-52.

[4] Awasthi S, Rani R, Malviya D. Peripheral venous blood gas analysis: An alternative to arterial blood gas analysis for initial assessment and resuscitation in emergency and intensive care unit patients. Anesthesia: Essays and Researches. 2013;7:355-8.

[5] Barras JP. Blood rheology - general review. Bibliotheca Haematologica. 1969;33:277-97.

[6] Barshtein G, Ben-Ami R, Yedgar S. Role of red blood cell flow behavior in hemodynamics and hemostasis. Expert Review of Cardiovascular Therapy. 2007;5(4):743-52.

[7] Baskurt OK, Meiselman HJ. Cellular determinants of low-shear blood viscosity. Biorheology. 1997;34(3):235-47.

[8] Baskurt OK, Meiselman HJ. Blood rheology and hemodynamics. Seminar Thrombosis Hemostasis. 2003;29(5): 435-50.

[9] Baskurt OK, Meiselman HJ. Hemodynamic effects of red blood cell aggregation. Indian Journal of Experimental Biology. 2007;45(1):25-31.

[10] Baskurt OK, Meiselman HJ. RBC aggregation: More important than RBC adhesion to endothelial cells as a determinant of in vivo blood flow in health and disease. Microcirculation. 2008;15(7):585-90.

[11] Baskurt OK, Temiz A, Meiselman HJ. Effect of superoxide anions on red blood cell rheologic properties. Free Radical Biology and Medicine. 1998;24:102-10.

[12] Baskurt OK, Uyuklu M, Meiselman HJ. Protection of erythrocytes from sub-hemolytic mechanical damage by nitric oxide mediated inhibition of potassium leakage. Biorheology. 2004;41(2):79-89.

[13] Baskurt OK, Yalcin O, Ozdem S, Armstrong JK, Meiselman HJ. Modulation of endothelial nitric oxide synthase expression by red blood cell aggregation. American Journal of Physiology-Heart and Circulatory Physiology. 2004;286(1):H222-9.

[14] Bateman RM, Jagger JE, Sharpe MD, Ellsworth ML, Mehta S, Ellis CG. Erythrocyte deformability is a nitric oxidemediated factor in decreased capillary density during sepsis. American Journal of Physiology-Heart and Circulatory Physiology. 2001;280(6):H2848-56.

[15] Bateman RM, Sharpe MD, Singer M, Ellis CG. The effect of sepsis on the erythrocyte. International Journal of Molecular Sciences. 2017;18(9):1932.

[16] Begum AN, Terao J. Protective effect of alpha-tocotrienol against free radical-induced impairment of erythrocyte deformability. Bioscience, Biotechnology, and Biochemistry. 2002;66(2):398-403.

[17] Bekyarova G, Yankova T, Kozarev I, Yankov D. Reduced erythrocyte deformability related to activated lipid peroxidation during the early postburn period. Burns. 1996;22(4):291-4.

[18] Bentzen PJ, Lang F. Effect of anandamide on erythrocyte survival. Cellular Physiology and Biochemistry. 2007;20(6):1033-42.

[19] Berent H, Wocial B, Kuczyńska K, Kochmański M, Ignatowska-Switalska H, Januszewicz A, Lapiński M, Lewandowski J, Januszewicz W. Evaluation of blood rheology indices in patients with pheochromocytoma. Polskie Archiwum Medycyny Wewnetrznej. 1996;95(3):190-7. 
[20] Bishop JJ, Nance PR, Popel AS, Intaglietta M, Johnson PC. Relationship between erythrocyte aggregate size and flow rate in skeletal muscle venules. American Journal of Physiology-Heart and Circulatory Physiology. 2004;286(1): H113-20.

[21] Bissinger R, Schumacher C, Qadri SM, Honisch S, Malik A, Götz F, Kopp HG, Lang F. Enhanced eryptosis contributes to anemia in lung cancer patients. Oncotarget. 2016;7(12):14002-14.

[22] Borgese F, Garcia-Romeu F, Motais R. Control of cell volume and ion transport by beta-adrenergic catecholamines in erythrocytes of rainbow trout, Salmo gairdneri. Journal of Physiology. 1987;382:123-44.

[23] Bor-Kuçukatay M, Wenby RB, Meiselman HJ, Baskurt OK. Effects of nitric oxide on red blood cell deformability. American Journal of Physiology-Heart and Circulatory Physiology. 2003;284(5):H1577-84.

[24] Brun J-F. Hormones, metabolism and body composition as major determinants of blood rheology: Potential pathophysiological meaning. Clinical Hemorheology and Microcirculation. 2002;26(2):63-79.

[25] Brun J-F, Bouchahda C, Aissa Benhaddad A, Sagnes C, Granat MC, Bor Kuçukatay M, Baskurt O, Mercier J. Hemorheological aspects of leuko-platelet activation in atheromatous diseases: Clinical applications. Journal des Maladies Vasculaires. 2000;25:349-55.

[26] Brun J-F, Connes P, Varlet-Marie E. Alterations of blood rheology during and after exercise are both consequences and modifiers of body's adaptation to muscular activity. Science \& Sports. 2007;22(6):251-66.

[27] Brun J-F, Fons C, El Bouhmadi A, Sekkat M, Orsetti A. Etude des facteurs liés aux modifications hémorhéologiques chez 60 obèses, XVIe réunion de la Société d'Angiologie de Langue Française, Montpellier, France, 19-20 Octobre 1990. Abstract book.

[28] Brun J-F, Fons C, Fussellier M, Bardet L, Orsetti A. Zinc salts improve in vitro erythrocyte flexibility, Revista portuguesa de hemorreologia. 1991;5:231-8.

[29] Brun J-F, Fons C, Raynaud EE, Fédou C, Orsetti A. Influence of circulating lactate on blood rheology during exercise in professional football players. Revista Portuguesa de Hemorreologia. 1991;5:219-29.

[30] Brun J-F, Gaudard A, Varlet-Marie E, Mercier J. Does hemorheology explain the paradox of hematocrit in training and overtraining? Science \& Sports. 2003;18:308-11.

[31] Brun J-F, Guiraudou M, Romain A-J, Pollatz M, Fédou C, Mercier J. The level of maximal lipid oxidation (LIPOXmax) as a level of exercise whose energetic and behavioural properties fit with the "thrifty genotype" of the metabolic syndrome: The hypothesis of the "healthy primitive lifestyle", Science \& Sports. 2015;30:74-81.

[32] Brun J-F, Pérez-Martin A, Fédou C, Mercier J. Insulin sensitivity and growth hormone status as two important endocrine determinants of blood rheology, IIIrd International Conference on Haemorheology, Yaroslavl, Russia, July 29-31th, 2001. Proceedings by A. Muravyov, I. Tikhomirova, V. Yakusevitch, L. G. Zaitsev, A.G. Gushin, I.A. Bakanova, D.V. Borisov, O.N. Semenova p. 41.

[33] Brun J-F, Rauturier M, Ghanem Y, Orsetti A. In vitro effects of somatostatin on red cell filterability measured by three methods. Journal des Maladies Vasculaires. 1991;16:49-52.

[34] Brun J-F, Varlet-Marie E. Type 2 diabetics with higher plasma viscosity exhibit a higher blood pressure, 12th European Conference on Clinical Haemorheology, Sofia, Bulgaria, June 22nd-26th, 2003 and EuroSummer School on Biorhelogy, Varna, Bulgaria, June 29th-July 2nd, 2003. Program and book of abstracts, 2003. p 61.

[35] Brun J-F, Varlet-Marie E, Aloulou I, Sardinoux M, Raynaud de Mauverger E, Mercier J. Hemorheology and insulin resistance, in: Microcirculation and Hemorheology, Wiernsperger N, ed., Bentham Science Publishers, 2009, pp. 99-106.

[36] Brun J-F, Varlet-Marie E, Cassan D, Manetta J, Mercier J. Blood fluidity is related to the ability to oxidize lipids at exercise, 12th European Conference on Clinical Haemorheology, Sofia, Bulgaria, June 22nd-26th, 2003 and EuroSummer School on Biorhelogy, Varna, Bulgaria, June 29th-July 2nd, 2003. Program and book of abstracts p. 53.

[37] Brun J-F, Varlet-Marie E, Chevance G, Pollatz M, Fedou C, Raynaud de Mauverger E. Versatility of 'hemorheologic fitness' according to exercise intensity: Emphasis on the "healthy primitive lifestyle", Korea-Australia Rheology Journal. 2014;26(2):1-5.

[38] Brun J-F, Varlet-Marie E, Connes P, Aloulou I. Hemorheological alterations related to training and overtraining. Biorheology. 2010;47(2):95-115.

[39] Brun J-F, Varlet-Marie E, Raynaud de Mauverger E. Blood rheology and body composition as determinants of exercise performance in middle-aged patients suffering from the metabolic syndrome, 16th International Conference of the European Society for Clinical Haemorheology and 30th annual conference of the German Society for Clinical Microcirculation, Munich, Germany, June 18th-21th, 2011. Abstract book p. 25.

[40] Burnstock G. Blood cells: An historical account of the roles of purinergic signaling. Purinergic Signal. 2015;11(4): 411-34.

[41] Bryszewska M, Leyko W. Effects of insulin on human erythrocyte membrane fluidity in diabetes mellitus. Diabetologia. 1983;24:311-3. 
[42] Cabel M, Meiselman HJ, Popel AS, Johnson PC. Contribution of red blood cell aggregation to venous vascular resistance in skeletal muscle. American Journal of Physiology-Heart and Circulatory Physiology. 1997;272:H1020-32.

[43] Cabrales P, Tsai AG. Plasma viscosity regulates systemic and microvascular perfusion during acute extreme anemic conditions. American Journal of Physiology-Heart and Circulatory Physiology. 2006;291(5):H2445-52.

[44] Catanese VM, Grigorescu F, King GL, Kahn CR. The human erythrocyte insulin-like growth factor I receptor: Characterization and demonstration of ligand-stimulated autophosphorylation. Journal of Clinical Endocrinology and Metabolism. 1986;62:692-9.

[45] Chen K, Popel AS. Nitric oxide production pathways in erythrocytes and plasma. Biorheology. 2009;46(2):107-19.

[46] Chien S. Present state of blood rheology. in: Hemodilution. Theoretical Basis and Clinical Application, K. Messmer, H. Schmid-Schonbein, ed., Karger, Basel, 1972, pp. 1-45.

[47] Chien S. Red cell deformability and its relevance to blood flow. Annual Review of Physiology. 1987;49:177-92.

[48] Chiocchia G, Motais R. Effect of catecholamines on deformability of red cells from trout: Relative roles of cyclic AMP and cell volume. Journal of Physiology. 1989;412:321-32.

[49] Cicha I, Suzuki Y, Tateishi N, Maeda N. Iron-induced oxidative damage in human red blood cells and the effect of thiol-containing antioxidants. Biorheology. 1999;36:48.

[50] Cicha I, Suzuki Y, Tateishi N, Maeda N. Effects of dietary triglycerides on rheological properties of human red blood cells, 12th Conference of the European Society of Clinical Hemorheology, Sofia, Bulgaria, June 22-26th, 2003.

[51] Connes P, Alexy T, Detterich J, Romana M, Hardy-Dessources MD, Ballas SK. The role of blood rheology in sickle cell disease. Blood Reviews. 2016;30(2):111-8.

[52] Connes P, Caillaud C, Bouix D, Kippelen P, Mercier J, Varray A, Préfaut C, Brun J-F. Red cell rigidity paradoxically decreases during maximal exercise in endurance athletes unless they are prone to exercise-induced hypoxaemia. Journal des Maladies Vasculaires. 2000;25:165.

[53] Cook JD, Finch CA. Assessing Iron status of a population. American Society for Nutrition. 1979;32:2115-9.

[54] Crawford J, Cox EB, Cohen HJ. Evaluation of hyperviscosity in monoclonal gammopathies. American Journal of Medicine. 1985;79:13-22.

[55] Dave JR, Eskay RL. Demonstration of corticotropin-releasing factor binding sites on human and rat erythrocyte membranes and their modulation by chronic ethanol treatment in rats. Biochemical and Biophysical Research Communications. 1986;136:137-44.

[56] Delamaire M, Durand F, Hamel D, Joyeux V, Lepogamp P, Genetet B. Improvement of hemorheologic parameters in hemodialyzed patients treated with human recombinant erythropoietin. Journal des Maladies Vasculaires. 1991;16(3):289-94.

[57] Di Loreto V, Rigalli A, Cinara L, Hernández G. Effect of disodium monofluorphosphate on plasma and blood viscosity in the rat. Clinical Hemorheology and Microcirculation. 2008;40(4):259-65.

[58] Dintenfass L. Blood viscosity, Hyperviscosity \& Hyperviscosaemia, Melbourne, MTP press, (1985), pp. 482.

[59] Donadello K, Piagnerelli M, Reggiori G, Gottin L, Scolletta S, Occhipinti G, Zouaoui Boudjeltia K, Vincent JL. Reduced red blood cell deformability over time is associated with a poor outcome in septic patients. Microvascular Research. 2015;101:8-14.

[60] Duez J, Holleran JP, Ndour PA, Pionneau C, Diakité S, Roussel C, Dussiot M, Amireault P, Avery VM, Buffet PA. Mechanical clearance of red blood cells by the human spleen: Potential therapeutic applications of a biomimetic RBC filtration method. Transfusion Clinique et Biologique. 2015;22(3):151-7.

[61] Dupuy-Fons C, Brun J-F, Mallart C, Carvajal J, Fussellier M, Bardet L, Orsetti A. In vitro influence of zinc and magnesium on the deformability of red blood cells artificially hardened by heating. Biological Trace Element Research. 1995;47:247-55.

[62] Dupuy-Fons C, Brun J-F, Mary A, Laborde J-C, Bachelot F, Janbon C. Correlations between blood rheology and transcutaneous $\mathrm{O}_{2}$ pressure in peripheral obliterative arterial disease, Joint meeting of the English Society of Rheology and the Société Française d'Hémorhéologie Fondamentale et Appliquée, Reims, France, October 22, 1992.

[63] Dupuy-Fons C, Brun J-F, Quere I, Bardet L, Janbon C. Rheology and occlusive arterial disease of the legs. Journal des Maladies Vasculaires. 1996;21(3):165-70.

[64] Dutta-Roy AK, Ray TK, Sinha AK. Control of erythrocyte membrane microviscosity by insulin. Biochimica et Biophysica Acta. 1985;816:187-90.

[65] Elgatit AM, Rashid MA, Belboul AM, Ramirez JJ, Roberts DG, Olsson GW. Effects of aprostadil (PGE1) on red and white cell deformability during cardiopulmonary bypass, VIIth European Conference on Clinical Haemorheology, Southampton, Angleterre, July 16-19th, 1991. Abstract book p. 81.

[66] Emamian M, Hasanian SM, Tayefi M, Bijari M, Movahedian F, Shafiee M, Avan A, Heidari-Bakavoli A, Moohebati M, Ebrahimi M, Darroudi S, Zamani P, Azarpazhooh MR, Nematy M, Safarian M, Ferns GA, Esmaeili H, Parizadeh 
MR, Ghayour-Mobarhan M. Association of hematocrit with blood pressure and hypertension. Journal of Clinical Laboratory Analysis 2017;31(6).

[67] Engström KG, Meiselman HJ. Effects of acid pH on the dynamic swelling behavior of age-separated RBC: Possible contribution to cell sequestration. VIIth European Conference on Clinical Haemorheology, Southampton (Angleterre) 16-19th July 1991. Abstract book p. 4527.

[68] Ernst E, Resch KL, Matrai A, Buhl M, Schlosser P, Paulsen HF. Impaired blood rheology: A risk factor after stroke? Journal of Internal Medicine. 1991;229:457-62.

[69] Forst T, De La Tour DD, Kunt T, Pfützner A, Goitom K, Pohlmann T, Schneider S, Johansson BL, Wahren J, Löbig M, Engelbach M, Beyer J, Vague P. Effects of proinsulin C-peptide on nitric oxide, microvascular blood flow and erythrocyte $\mathrm{Na}^{+}, \mathrm{K}^{+}$-ATPase activity in diabetes mellitus type I, Clinical Science. 2000;98(3):283-90.

[70] Forsyth AM, Braunmüller S, Wan J, Franke T, Stone HA. The effects of membrane cholesterol and simvastatin on red blood cell deformability and ATP release. Microvascular Research. 2012;83(3):347-51.

[71] Fuse I, Ito S, Takagi A, Shibata A. Different effects of three kinds of somatostatin (15-28, 1-14, 1-28) on rabbit's platelet aggregation. Life Sciences. 1985;36:2047-52.

[72] Gaehtgens P. Distribution of flow and red cell flux in the microcirculation. Scandinavian Journal of Clinical and Laboratory Investigation. 1981;156:83-7.

[73] Goldsmith HL, Cokelet GR, Gaehtgens P. Robin Fåhraeus: Evolution of his concepts in cardiovascular physiology. American Journal of Physiology. 1989;257(3):H1005-15.

[74] Gopalakrishnan V, Ramaswamy S, Pillai NP, Ranganathan S, Cosh MN. Effect of prolactin on human red cell sodium transport. Experientia. 1980;36:1423-5.

[75] Gotoh S, Hata J, Ninomiya T, Hirakawa Y, Nagata M, Mukai N, Fukuhara M, Ikeda F, Ago T, Kitazono T, Kiyohara Y. Hematocrit and the risk of cardiovascular disease in a Japanese community: The Hisayama Study. Atherosclerosis. 2015;242(1):199-204.

[76] Grau M, Mozar A, Charlot K, Lamarre Y, Weyel L, Suhr F, Collins B, Jumet S, Hardy-Dessources MD, Romana M, Lemonne N, Etienne-Julan M, Antoine-Jonville S, Bloch W, Connes P. High red blood cell nitric oxide synthase activation is not associated with improved vascular function and red blood cell deformability in sickle cell anaemia. British Journal of Haematology. 2015;168(5):728-36.

[77] Gu YJ, Vermeijden WJ, de Vries AJ, Hagenaars JA, van Oeveren W, Graaff R. Influence of mechanical cell salvage on red blood cell aggregation, deformability, and 2,3-diphosphoglycerate in patients undergoing cardiac surgery with cardiopulmonary bypass. Annals Thoracic Surgery. 2008;86:1570-5.

[78] Guézennec CY, Nadaud JF, Satabin P, Léger C, Laffargue P. Influence of polyunsaturated fatty acid diet on the hemorheological response to physical exercise in hypoxia. International Journal of Sports Medicine. 1989;10:286-91.

[79] Guyton AC, Richardson TQ. Effect of hematocrit on venous return. Circulation Research. 1961;9:157-64.

[80] Ham TH, Shen SC, Fleming EM. Studies on the destruction of red blood cells; thermal injury; action of heat in causing increased spheroidicity, osmotic and mechanical fragilities and hemolysis of erythrocytes; observations on the mechanisms of destruction of such erythrocytes in dogs and in a patient with a fatal thermal burn. Blood. 1948;3(4):373403.

[81] Hänggi P, Makhro A, Gassmann M, Schmugge M, Goede JS, Speer O, Bogdanova A. Red blood cells of sickle cell disease patients exhibit abnormally high abundance of $\mathrm{N}$-methyl D-aspartate receptors mediating excessive calcium uptake. British Journal of Haematology. 2014;167(2):252-64.

[82] Hilario S, Saldanha C, Martins-Silva J. The effect of adrenaline upon human erythrocyte. Sex-related differences? Biorheology. 1999;36:124.

[83] Hopps E, Caimi G. Obstructive Sleep Apnea Syndrome: Links Betwen Pathophysiology and Cardiovascular Complications. Clinical and Investigative Medicine. 2015;38:E362-70.

[84] Hopps E, Canino B, Calandrino V, Montana M, Lo Presti R, Caimi G. Lipid peroxidation and protein oxidation are related to the severity of OSAS. European Review for Medical and Pharmacological Sciences. 2014;24:3773-8.

[85] Irace C, Scavelli F, Carallo C, Serra C, Gnasso A. Plasma and blood viscosity in metabolic syndrome. Nutrition Metabolism and Cardiovascular Diseases. 2009;19:476-80.

[86] Jae SY, Kurl S, Laukkanen JA, Heffernan KS, Choo J, Choi YH, Park JB. Higher blood hematocrit predicts hypertension in men. Journal of Hypertension. 2014;32(2):245-50.

[87] Jain RK, Traykov TT. Effect of glucose and galactose on RBC deformability. Biorheology. 1986;23:292.

[88] Jemaá M, Fezai M, Lang F. Inhibition of suicidal erythrocyte death by reversine. Cellular Physiology and Biochemistry. 2017;41(6):2363-73.

[89] Joré C, Brun J-F, Varlet-Marie E. Rise in RBC aggregability and concomitant decrease in blood pressure 10 days after injection of the long acting erythropoietin analogue methoxy polyethylene glycol-epoetin- $\beta$ (MIRCERA®), 18th Conference of the European Society for Clinical Haemorheology, Lisboa, Portugal, June 5th-8th 2016. 
[90] Juhan I, Vague P, Buonocore M, Moulin JP, Jouve R, Vialettes B. Abnormalities of erythrocyte deformability and platelet aggregation in insulin-dependent diabetics corrected by insulin in vivo and in vitro. Lancet. 1982;1(8271): 535-7.

[91] Jung F, Rampling M. Role of blood viscosity in the microcirculation. Clinical Hemorheology and Microcirculation. 2016;64:251-4.

[92] Kartal H, Comu FM, Kucuk A, Polat Y, Dursun AD, Arslan M. Effect of apelin-13 on erythrocyte deformability during ischaemia-reperfusion injury of heart in diabetic rats. Bratislava Medical Journal. 2017;118(3):133-6.

[93] Kaukonen KM, Vaara ST, Pettilä V, Bellomo R, Tuimala J, Cooper DJ, Krusius T, Kuitunen A, Reinikainen M, Koskenkari J. Age of red blood cells and outcome in acute kidney injury. Critical Care. 2013;17(5):R222.

[94] Kersh GJ, Tomish JM, Montal M. The M2 delta transmembrane domain of the nicotinic cholinergic receptor forms ion channels in human erythrocyte membranes. Biochemical and Biophysical Research Communications. 1989;162:352-6.

[95] Késmárky G, Gábor, Kenyeres P, Rábai M, Tóth K. Plasma viscosity: A forgotten variable. Clinical Hemorheology and Microcirculation. 2008;39(1-4):243-6.

[96] Kiedaisch V, Akel A, Niemoeller OM, Wieder T, Lang F. Zinc-induced suicidal erythrocyte death. American Journal of Clinical Nutrition. 2008;87(5):1530-4.

[97] Kiesewetter H, Jung F, Wenzel E, Müller G. Variance, factors of influence and clinical relevance of plasma viscosity. Biomedizinische Technik. 1991;36:241-7.

[98] Kobayashi S, Hamazaki T, Sawazaki S, Nakamura H. Reduction in the ADP release from shear-stressed red blood cells by fish oil administration. Thrombosis Research. 1992;65(3):353-64.

[99] Koenig W, Ernst E. The possible role of hemorheology in atherothrombogenesis. Atherosclerosis. 1992;94:93-107.

[100] Koenig W, Sund M, Lowel H, Doring A, Ernst E. Association between plasma viscosity and all-cause mortality: Results from the MONICA-Augsburg Cohort Study 1984-92, British Journal of Haematology. 2000;109:453-8.

[101] Korbut R, Gryglewski RJ. Nitric oxide from polymorphonuclear leukocytes modulates red blood cell deformability in vitro. European Journal of Pharmacology. 1993;234:17-22.

[102] Korbut R, Gryglewski RJ. The effect of prostacyclin and nitric oxide on deformability of red blood cells in septic shock in rats. Journal of Physiology Pharmacology. 1996;47:591-9.

[103] Koutsouris D, Delatour-Hanss E, Hanss M. Physico-chemical factors of erythrocyte deformability. Biorheology. 1985;22(2):119-32.

[104] Kucukatay V, Bor-Kucukatay M, Gundogdu G, Erken G, Ozcan TO, Miloglu FD, Kadioglu Y. Vitamin E treatment enhances erythrocyte deformability in aged rats. Folia Biologica (Praha). 2012;58(4):157-65.

[105] Kwaan HC, Bongu A. The hyperviscosity syndromes. Seminars in Thrombosis and Hemostasis. 1999;25:199-208.

[106] Lang PA, Kempe DS, Akel A. Inhibition of erythrocyte 'apoptosis' by catecholamines. Naunyn-Schmiedeberg's. Archives of Pharmacology. 2005;372(3):228-35.

[107] Lang E, Lang F. Triggers, inhibitors, mechanisms, and significance of eryptosis: The suicidal erythrocyte death. BioMed Research International. 2015;2015:513518.

[108] Lanotte L, Mauer J, Mendez S, Fedosov DA, Fromental JM, Claveria V, Nicoud F, Gompper G, Abkarian M. Red cells' dynamic morphologies govern blood shear thinning under microcirculatory flow conditions. Proceedings of the National Academy of Sciences USA. 2016;47:13289-94.

[109] Le Devehat C, Khodabandehlou V, Vimeux M. Relationship between hemorheological and microcirculatory abnormalities in diabetes mellitus. Diabete Metabolism. 1994;20(4):401-4.

[110] Léger CL, Guézennec CY, Kadri-Hassani N, Satabin P. Les acides gras phospholipidiques membranaires au cours de l'effort physique de longue durée avec ou sans apport nutritionnel d'huiles de poissons. Cahiers de Nutrition et de Diététique. 1992;27:82-9.

[111] Lemonne N, Billaud M, Waltz X, Romana M, Hierso R, Etienne-Julan M, Connes P, Rheology of red blood cells in patients with $\mathrm{HbC}$ disease. Clinical Hemorheology and Microcirculation. 2016;61(4):571-7.

[112] Leonhardt H, Arntz H-R, Klemens UH. Studies of plasma viscosity in primary hyperlipoproteinaemia. Atherosclerosis. 1977;28:29-40.

[113] Linde T, Sandhagen B, Berne C, Lind L, Reneland R, Hanni A, Lithell H. Erythrocyte deformability is related to fasting insulin and declines during euglycaemic hyperinsulinaemia in hypertensive patients. Journal of Human Hypertension. 1999; 13:285-6.

[114] Lipowsky HH, Blood rheology aspects of the microcirculation, in: Handbook of Hemorheology and Hemodynamics. O.K. Baskurt, M.R. Hardeman, M.W. Rampling, H.J. Meiselman, ed., IOS Press, Amsterdam, 2007, pp. 307-21.

[115] Lipowsky HH, Kovalcheck S. The distribution of blood rheological parameters in the microvasculature of cat mesentery. Circulation Research. 1978;43(5):738-49.

[116] Lockwood SY, Erkal JL, Spence DM. Endothelium-derived nitric oxide production is increased by ATP released from red blood cells incubated with hydroxyurea. Nitric Oxide. 2014;38:1-7. 
[117] Lowe GDO, Fowkes FGR, Dawes J, Donnan PT, Lennie SE, Housley E. Blood viscosity, fibrinogen, and activation of coagulation and leukocytes in peripheral arterial disease and the normal population in the Edinburgh Artery Study. Circulation. 1993;87:1915-20.

[118] Lowe GDO, Wood DA, Douglas JT, Riemersma RA, McIntyre CC, Takase I, Tuddenham EG, Forbes CD, Elton RA, Oliver MF. Relationships of plasma viscosity, coagulation and and fibrinolysis to coronary risk factors and angina. Thrombosis Haemostasis. 1991;65:339-43.

[119] Makhro A, Hänggi P, Goede JS, Wang J, Brüggemann A, Gassmann M, Schmugge M, Kaestner L, Speer O, Bogdanova A. N-methyl-D-aspartate receptors in human erythroid precursor cells and in circulating red blood cells contribute to the intracellular calcium regulation. American Journal of Physiology-Cell Physiology. 2013;305(11): C1123-38.

[120] Mark M, Walter R, Harris LG, Reinhart WH. Influence of parathyroid hormone. calcitonin, $1,25(\mathrm{OH})_{2}$ cholecalciferol, calcium, and the calcium ionophore A23187 on erythrocyte morphology and blood viscosity. Journal of Laboratory and Clinical Medicine. 2000;135(4):347-52.

[121] Martini J, Carpentier B, Chávez Negrete A, Frangos JA, Intaglietta M. Paradoxical hypotension following increased hematocrit and blood viscosity. American Journal of Physiology-Heart and Circulatory Physiology. 2005;289: H2136-43.

[122] McNamee AP, Sabapathy S, Singh I, Horobin J, Guerrero J, Simmonds MJ. Acute free-iron exposure does not explain the impaired haemorheology associated with haemochromatosis. PLoS One. 2016;11(1):e0146448.

[123] Meier U, Gressner AM. Endocrine regulation of energy metabolism: Review of pathobiochemical and clinical chemical aspects of leptin, ghrelin, adiponectin, and resistin. Clinical Chemistry. 2004;50(9):1511-25.

[124] Meiselman HJ, Neu B, M.W.Rampling, OBaskurt K. RBC aggregation: Laboratory data and models. Indian Journal of Experimenal Biology. 2007;45:9-17.

[125] Miko I, Nemeth N, Sipka S Jr, E Brath, Peto K, A Gulyas, Furka A, Zhong R. Hemorheological follow-up after splenectomy and spleen autotransplantation in mice. Microsurgery. 2006;26(1):38-42.

[126] Montagnani M, Vulpis V, Nazzaro P, Potenza MA, Rinaldi R, Nacci C, De Salvia MA, Siro Brigiani G, Pirrelli A, Mitolo-Chieppa D. Endothelin-1-receptor-mediated responses in resistance vessels of young and adult spontaneously hypertensive rats. Journal of Hypertension. 2000;18(7):893-900.

[127] Mozar A, Connes P, Collins B, Hardy-Dessources MD, Romana M, Lemonne N, Bloch W, Grau M. Red blood cell nitric oxide synthase modulates red blood cell deformability in sickle cell anemia. Clinical Hemorheology and Microcirculation. 2016;64(1):47-53.

[128] Munter WA, Stein PD. Newtonian behavior of blood at high rates of shear. Biorheology. 1983;20(6):745-59.

[129] Muravyov A, Tikhomirova I. Signaling pathways regulating red blood cell aggregation. Biorheology. 2014;51(23):135-45.

[130] Murray J-F, Gold P, Johnson Jr B-L, The circulatory effects of hematocrit variations in normovolemic and hypervolemic dogs. Journal of Clinical Investigation. 1963;42;1150-9.

[131] Nanjo F, Honda M, Okushio K, Matsumoto N, Ishigaki F, Ishigami T, Hara Y. Effects of dietary tea catechins on alpha-tocopherol levels, lipid peroxidation, and erythrocyte deformability in rats fed on high palm oil and perilla oil diets. Biological and Pharmaceutical Bulletin. 1993;16(11):1156-9.

[132] Newman DL, Twinn KW. The influence of plasma cholesterol on whole blood and plasma viscosity. Biorheology. 1973;10(4):527-31.

[133] Nicolay JP, Liebig G, Niemoeller OM, Koka S, Ghashghaeinia M, Wieder T, Haendeler J, Busse R, Lang F. Inhibition of suicidal erythrocyte death by nitric oxide. Pflugers Archiv. 2008;456(2):293-305.

[134] Niemoeller OM, Bentzen PJ, Lang E, Lang F. Adenosine protects against suicidal erythrocyte death. Pflugers Archiv. 2007;454(3):427-39.

[135] Nwose EU. Whole blood viscosity assessment issues II: Prevalence in endothelial dysfunction and hypercoagulation. North American Journal of Medical Science. 2010;2(6):252-7.

[136] Olson JM, Ciliax BJ, Mancini WR, Young AB. Presence of peripheral-type benzodiazepine binding sites on human erythrocyte membranes. European Journal of Pharmacology. 1988;152:47-53.

[137] Oonishi K, Sakashita N, Uysaka N. Regulation of red blood cell filterability by $\mathrm{Ca}^{2+}$ influx and cAMP-mediated signaling pathways. American Journal of Physiology. 1997;273:C1828-34.

[138] Oostenbrug GS, Mensink RP, Hardeman MR, De Vries T, Brouns F, Hornstra G. Exercise performance, red blood cell deformability, and lipid peroxidation: Effects of fish oil, vitamin E. Journal of Applied Physiology. 1985;83(3):746-52.

[139] Parish JM, Somers VK. Obstructive sleep apnea and cardiovascular disease. Mayo Clinic Proceedings. 2004;79(8):1036-46.

[140] Perkkiö J, Wurzinger LJ, Schmid-Schönbein H. Fåhraeus-Vejlens effect: Margination of platelets and leukocytes in blood flow through branches. Thrombosis Research. 1988;50(3):357-64. 
[141] Pettilä V, Westbrook AJ, Nichol AD, Bailey MJ, Wood EM, Syres G, Phillips LE, Street A, French C, Murray L, Orford N, Santamaria JD, Bellomo R, Cooper DJ. Blood Observational Study Investigators for ANZICS Clinical Trials Group. Age of red blood cells and mortality in the critically ill. Critical Care. 2011;15(2):R116.

[142] Pichon AP, Connes P, Robach P. Effects of acute and chronic hematocrit modulations on blood viscosity in endurance athletes. Clinical Hemorheology and Microcirculation. 2016;64(2):115-23.

[143] Piskuric NA, Zhang M, Vollmer C, Nurse CA. Potential roles of ATP and local neurons in the monitoring of blood $\mathrm{O}_{2}$ content by rat aortic bodies. Experimental Physiology. 2014;99(1):248-61.

[144] Poiseuille JLM. Recherches expérimentales sur le mouvement des liquides dans les tubes de très petits diamètre. Comptes rendus des séances de l'Académie des Sciences. 1840;11:1041-8.

[145] Poraicu D, Mogoseanu A, Tomescu N, Bota C, Menessy I. Decrease of red blood cell filterability seen in intensive care I. The correlation of low erythrocyte filterability with mortality and its return to normal values in critically ill patients under parenteral nutrition Resuscitation. 1983;10(4):291-303.

[146] Powell RJ, Machiedo GW, Rush BF, Dikdan G. Oxygen free radicals: Effect on red cell deformability in sepsis. Critical Care Medicine. 1991;19(5):732-5.

[147] Pretorius E, du Plooy JN, Bester J. A comprehensive review on eryptosis. Cellular Physiology and Biochemistry. 2016;39(5):1977-2000.

[148] Prothero J, Burton AC. The physics of blood flow in capillaries. I. The nature of the motion. Biophysical Journal. 1961;1:565-79.

[149] Qadri SM, Bissinger R, Solh Z, Oldenborg PA. Eryptosis in health and disease: A paradigm shift towards understanding the (patho)physiological implications of programmed cell death of erythrocytes. Blood Review. 2017;31(6):349-61.

[150] Rabhi Y, Charras-Arthapignet C, Gris J-C, Ayoub J, Brun J-F, Lopez F-M, Janbon C, Marès P, Dauzat M. Lower limb vein enlargement and spontaneous blood flow echogenicity are normal sonographic findings during pregnancy. Journal of Clinical Ultrasound. 2000;28(8):407-13.

[151] Rahmani-Jourdheuil D, Mourayre Y, Vague P, Boyer J, Juhan-Vague I. In vivo insulin effect on ATPase activities in erythrocyte membrane from insulin-dependent diabetes. Diabetes. 1987;36:991-5.

[152] Rampling MW, Meiselman HJ, Neu B, Baskurt OK. Influence of cell-specific factors on red blood cell aggregation. Biorheology. 2004;41(2):91-112.

[153] Rao K, Shenoy SB, Kamath Y, Kapoor S. Central retinal artery occlusion as a presenting manifestation of polycythaemia vera. British Medical Journal Case Report. 2016;20:2016.

[154] Reinhart WH, Molecular biology and self-regulatory mechanisms of blood viscosity: A review. Biorheology. 2001;38(2-3):203-12.

[155] Reinhart WH, The optimum hematocrit. Clinical Hemorheology and Microcirculation. 2016;64(4):575-85.

[156] Reinhart WH, Geissmann-Ott C, Bogdanova A. Activation of N-methyl D-aspartate (NMDA) receptors has no influence on rheological properties of erythrocytes, 16th Conference of the European Society for Clinical Haemorheology, Munich, Germany, June 18th-21th, 2011.

[157] Reinhart WH, Piety NZ, Deuel JW, Makhro A, Schulzki T, Bogdanov N, Goede JS, Bogdanova A, Abidi R, Shevkoplyas SS. Washing stored red blood cells in an albumin solution improves their morphologic and hemorheologic properties. Transfusion. 2015;55(8):1872-81.

[158] Reinhart WH, Reinhart SA, Schulzki T. Erythrocyte alterations during blood storage, 17th Conference of the European Society for Clinical Haemorheology Pécs, Hungary, July 6-9th, 2013.

[159] Reinhart WH, Schulzki T. Metabolic depletion decreases the aggregability of erythrocytes, 16th Conference of the European Society for Clinical Haemorheology Munich, Germany, June 18th-21th, 2011.

[160] Resch KL, Ernst E, Matrai A, Paulsen HF. Fibrinogen and viscosity as risk factors for subsequent cardiovascular events in stroke survivors. Annals of Internal Medicine. 1992;117:371-5.

[161] Rey J, Buffet PA, Ciceron L, Milon G, Mercereau-Puijalon O, Safeukui I. Reduced erythrocyte deformability associated with hypoargininemia during Plasmodium falciparum malaria. Scientific Reports. 2014;4:3767.

[162] Robey C, Dasmahapatra A, Cohen M, Suarez S. Sorbinil partially prevents decreased erythrocyte deformability in experimental diabetes mellitus. Diabetes. 1987;36:1010-3.

[163] Sakashita K, Oonishi T, Ishioka N, Uyesaka N. Endothelin-1 improves the impaired filterability of red blood cells through the activation of protein kinase C, Japanese Journal of Physiology. 1999;49(1):113-20.

[164] Salazar Vázquez BY, Cabrales P, Tsai AG, Johnson PC, Intaglietta M. Lowering of blood pressure by increasing hematocrit with non-nitric oxide-scavenging red blood cells. American Journal of Respiratory Cell and Molecular Biology. 2008;38(2):135-42.

[165] Salazar Vázquez BY, Martini J, Tsai AG, Johnson PC, Cabrales P, Intaglietta M. The variability of blood pressure due to small changes of hematocrit. American Journal of Physiology Heart and Circulatory Physiology. 2010;299(3):H863-7.

[166] Saldanha C. Instrumental analysis applied to erythrocyte properties. Journal of Cellular Biotechnology. 2015;1:81-93. 
[167] Saldanha C, Human Erythrocyte Acetylcholinesterase in Health and Disease. Molecules. 2017;22:1499-2009.

[168] Saldanha C, Martins-Silva E. Effect of plasma osmolality on erythrocyte aggregation index, in: Hemorhéologie et Agrégation erythrocytaire vol 3, Editions Médicales Internationales, 1990, pp. 142-5.

[169] Savi L, Cardillo C, Bombardieri G. Somatostatin and peripheral blood flow in man. Angiology. 1985;36:511-5.

[170] Schmalzer EA, Lee JO, Brown AK, Usami S, Chien S. Viscosity of mixtures of sickle and normal red cells at varying hematocrit levels. Implications for transfusion. Transfusion. 1987;27(3):228-33.

[171] Schmid-Schönbein H. Wege des Infarzierens. Neue erkenntinisse durch die in-vivo-rheoskopie. Internist (Berl). 2001;42(9):1196-2000.

[172] Schmid-Schönbein H. Percolation theory: Rheological factors determine both intravascular flow and transcapillary exchange, in: Proceedings of the 3rd International Conference on Haemorheology, A. Muravyov, Tikhomirova I, Yalusevitch V, Zaitsev LG, Gushin AG, Bakanova IA, D.V. Borisov and O.N. Semenova ed., Yaroslavl, Russia 29-31 July 2002, pp. 117.

[173] Schmid-Schönbein H, Gaehtgens P. What is red cell deformability? Scandinavian Journal of Clinical and Laboratory Investigation. 1981;156:13-26.

[174] Schmid-Schönbein H, Teitel P. In vitro assessment of "covertly" abnormal blood rheology: Critical appraisal of presently available microrheological methodology. A review focusing on diabetic retinopathy as a possible consequence of rheological occlusion, Fifth European Conference on Clinical Haemorheology, Bordeaux, France, June 29th - July 1st, 1987. Abstracts.

[175] Schmid-Schönbein H, Volger E. Red cell aggregation and red cell deformability in diabetes. Diabetes. 1976;25:897902.

[176] Schmidt R, Lerche D, Dörp E, Winkler R, Klinkmann H. Changes in rheology and red blood cell function under recombinant human erythropoietin therapy. Polskie Archiwum Medycyny Wewnetrznej. 1991;85(6):384-90.

[177] Schütz E, Schuff-Werner P, Armstrong VW, Senger I, Güttner Y. Haemorheological changes during postprandial lipemia, VIIth European Conference on Clinical Haemorheology, Southampton (UK) 16-19th July 1991. Abstract book p. 91.

[178] Sentürk UK, Gündüz F, Kuru O, Aktekin MR, Kipmen D, Yalçin O, Bor-Küçükatay M, YeŞilkaya A, Başkurt OK. Exercise-induced oxidative stress affects erythrocytes in sedentary rats but not exercise-trained rats. Journal of Applied Physiology. 1985;91(5):1999-2004.

[179] Sentürk UK, Gündüz F, Kuru O, Koçer G, Ozkaya YG, Yesilkaya A, Bor-Küçükatay M, Uyüklü M, Yalçin O, Baskurt OK. Exercise-induced oxidative stress leads hemolysis in sedentary but not trained humans. Journal of Applied Physiology. 1985;99(4):1434-41.

[180] Seplowitz AH, Chien S, Smith FR. Effects of lipoproteins on plasma viscosity. Atherosclerosis. 1981;38:89-95.

[181] Shin S, Ku Y, Babu N, Singh M. Erythrocyte deformability and its variation in diabetes mellitus. Indian Journal of Experimenal Biology. 2007;45:121-8.

[182] Silva-Herdade AS, Andolina G, Faggio C, Calado Â, Saldanha C. Erythrocyte deformability - A partner of the inflammatory response. Microvascular Research. 2016;107:34-8.

[183] Simmonds MJ, Detterich JA, Connes P. Nitric oxide, vasodilation and the red blood cell. Biorheology. 2014;51(23):121-34.

[184] Singh A, Eckardt KU, Zimmermann A, Götz KH, Hamann M, Ratcliffe PJ, Kurtz A, Reinhart WH. Increased plasma viscosity as a reason for inappropriate erythropoietin formation. Journal of Clinical Investigation. 1993;91(1): 251-6.

[185] Skalak R, Chien S. Rheology of blood cells as soft tissues. Biorheology. 1982;19(3):453-61.

[186] Skovborg F, Nielsen AV, Schlichtkrull J, Ditzel J. Blood viscosity in diabetic patients. Lancet. 1966;1:129.

[187] Sluyter R. P2X and P2Y receptor signaling in red blood cells. Frontiers in Molecular Biosciences. 2015;2:60.

[188] Solá E, Vayá A, Corella D, Santaolaria ML, España F, Estellés A, Hernández-Mijares A. Erythrocyte hyperaggregation in obesity: Determining factors and weight loss influence. Obesity. 2007;15(8):2128-34.

[189] Sprague RS, Ellsworth ML, Stephenson AH, Lonigro AJ. ATP: The red blood cell link to NO and local control of the pulmonary circulation. American Journal of Physiology. 1996;271:H2717-22.

[190] Stuart J, Juhan-Vague I. Erythrocyte rheology in diabetes. Biorheology. 1986;23:216.

[191] Sundquist J, Bias DS, Hogan JE, Davis FB, Davis PJ. The $\alpha 1$-adrenergic receptor in human erythrocyte membranes mediates interaction in vitro of epinephrine and thyroid hormone at the membrane $\mathrm{Ca}^{2+}$-ATPase. Cellular Signalling. 1992;4:795-9.

[192] Sung LA, Kabbat EA, Chien S. Interaction of lectins with membrane receptors on erythrocyte surfaces. Journal of Cell Biology. 1985;101:646-51.

[193] Takamizawa K, Hayashi K, Nakamura T, Kato T, Tsushima N. Change of hematocrit and blood viscosity in cholesterolfed rabbits. Biorheology. 1988;25(6):869-77. 
[194] Tang LC. Identification and characterization of human erythrocyte muscarinic receptors. General Pharmacology. 1986;17:281-5.

[195] Tażbirek M, Slowińska L, Kawalski M. Pierzchała W. The rheological properties of blood and the risk of cardiovascular disease in patients with obstructive sleep apnea syndrome (OSAS), Folia Histochemica et Cytobiologica. 2011;49(2):206-10.

[196] Thoth K, Ernst E, Habon T, Horvath I, Juricskay I, Mozsic G. Hemorheological and hemodynamical effects of fish oil (Ameu) in patients with ischemic heart disease and hyperlipoproteinemia, 9th European Conference on Clinical Haemorheology, Siena, Italy, June 29th-July 1st, 1995. Abstracts.

[197] Tikhomiroiva IA, Muravyov AV, Kruglova EV. Hormonal control mechanisms of the rheological properties of erythrocytes under physical exercises and stress. Biorheology. 2008;45(1-2):49.

[198] Tomaiuolo G, Lanotte L, D'Apolito R, Cassinese A, Guido S. Microconfined flow behavior of red blood cells. Medical Engineering \& Physics. 2016;38(1):11-6.

[199] Tsai AG, Acero C, Nance PR, Cabrales P, Frangos JA, Buerk DG, Intaglietta M. Elevated plasma viscosity in extreme hemodilution increases perivascular nitric oxide concentration and microvascular perfusion. The American Journal of Physiology-Heart and Circulatory Physiology. 2005;288:H1730-9.

[200] Ulker P. The effect of acute and short term normobaric hyperoxia on hemorheologic parameters. Biorheology. 2016;53(3-4):171-7.

[201] Ulker P, Sati L, Celik-Ozenci C, Meiselman HJ, Baskurt OK. Mechanical stimulation of nitric oxide synthesizing mechanisms in erythrocytes. Biorheology. 2009;46(2):121-32.

[202] Unal Y, Comu FM, Emik U, Alkan M, Pampal HK, Arslan M. The effects of propofol and memantine on erythrocyte deformability. Bratislavske Lekarske Listy. 2014;115(5):253-5.

[203] Vague P, Juhan I. Red cell deformability, platelet aggregation, and insulin action. Diabetes. 1983;32:88-91.

[204] Valensi P, Gaudey F, Attali JR. La déformabilité érythrocytaire est réduite par le glucagon. Diabetes Metabolism. 1986;12:281.

[205] Van Beaumont W, Greenleaf JE, Juhos L. Disproportional changes in hematocrit, plasma volume and proteins during exercise and bed rest. Journal of Applied Physiology. 1972;33:55-61.

[206] Varlet-Marie E, Guiraudou M, Fédou C, Raynaud de Mauverger E, Durand F, Brun J-F. Nutritional and metabolic determinants of blood rheology differ between trained and sedentary individuals, 17th Conference of the European Society for Clinical Haemorheology and Microcirculation, Pécs, Hungary, July 6-9th, 2013.

[207] Vicaut E, Hou X, Decuypère L, Taccoen A, Duvelleroy M. Red blood cell aggregation and microcirculation in rat cremaster muscle. International Journal of Clinical and Experimental Medicine. 1994;14(1-2):14-21.

[208] Vogel J, Kiessling I, Heinicke K, Stallmach T, Ossent P, Vogel O, Aulmann M, Frietsch T, Schmid-Schönbein H, Kuschinsky W, Gassmann M. Transgenic mice overexpressing erythropoietin adapt to excessive erythrocytosis by regulating blood viscosity. Blood. 2003;102(6):2278-84.

[209] Vota DM, Maltaneri RE, Wenker SD, Nesse AB, Vittori DC. Differential erythropoietin action upon cells induced to eryptosis by different agents. Cell Biochemistry and Biophysics. 2013;65(2):145-57.

[210] Walter R, Mark M, Harris LG, Reinhart WH. In vitro influence of nitrovasodilators and endothelin-1 on rheology of human blood. Biorheology. 1999;36:96.

[211] Wang L, Olivecrona G, Götberg M, Olsson ML, Winzell MS, Erlinge D. ADP acting on P2Y13 receptors is a negative feedback pathway for ATP release from human red blood cells. Circulation Research. 2005;96(2): 189-96.

[212] Weng X, Cloutier G, Beaulieu R, Roederer GO. Influence of acute-phase proteins on erythrocyte aggregation. American Journal of Physiology. 1996;271(6):H2346-52.

[213] Weng X, Roederer GO, Beaulieu R, Cloutier G. Contribution of acute-phase proteins and cardiovascular risk factors to erythrocyte aggregation in normolipidemic and hyperlipidemic individuals. Thrombosis and Haemostasis. 1998;80(6):903-8.

[214] Windberger U, Bartholovitsch A. Hemorheology in spontaneous animal endocrinopathies. Clinical Hemorheology and Microcirculation. 2004;31(3):207-15.

[215] Wong WW, Jack RM, Smith JA, Kennedy CA, Fearon DT. Rapid purification of the human C3b/C4b receptor (CR1) by monoclonal antibody affinity chromatography. Journal of Immunological Methods. 1985;82:303-13.

[216] Yarnell JWG, Baker IA, Sweetnam PM, Bainton D, O'Brien JR, Whitehead PJ, Elwood PC. Fibrinogen, viscosity and white blood cell count are major risk factors for ischemic heart disease. The Caerphilly and Speedwell Heart Disease studies. Circulation. 1991;83:836-44.

[217] Yerer MB, Aydogan S. The in vivo antioxidant effectiveness of alpha-tocopherol in oxidative stress induced by sodium nitroprusside in rat red blood cells, 12th Conference of the European Society of Clinical Hemorheology, Sofia, Bulgaria, June 22-26th, 2003. 
[218] Zhong Y, Lin SL, Schooling CM. The effect of hematocrit and hemoglobin on the risk of ischemic heart disease: A Mendelian randomization study. Preventive Medicine. 2016;91:351-5.

[219] Zimmerman RS, Martinez AJ, Maymind M, Barbee RW. Effect of endothelin on plasma volume and albumin escape. Circulation Research. 1992;70(5):1027-34.

[220] Zimmermann J, Schramm L, Wanner C, Mulzer E, Henrich HA, Langer R, Heidbreder E. Hemorheology, plasma protein composition and von Willebrand factor in type I diabetic nephropathy. Clinical Nephrology. 1996;46(4):230-6.

[221] Zyznar ES, Pietri AO, Harris V, Unger RH. Evidence for the hormonal status of somatostatin in man. Diabetes. 1981;30:883-6. 